\title{
The Global Convergence of Global Settlements
}

\author{
Adam S. Zimmerman*
}

Conventional wisdom says that the American-style class action will never go global. Even as some countries develop innovative ways to handle enormous cases - from Netherland's settlement-only approach to mass torts ${ }^{1}$ to Japan's recent adoption of class actions ${ }^{2}$ - a number of factors have slowed their growth abroad. Such barriers include: (1) bans on contingency fees, (2) "loser-pay" rules that increase the financial risk of complex litigation for plaintiffs, and (3) collective actions that, in many cases, require that all parties affirmatively "opt-in" to participate. ${ }^{3}$ These features of collective actions will continue to limit the incentives, stakes, and finality of large settlements forged overseas. ${ }^{4}$

This resistance reflects, in some ways, what some say is the uniquely "bottom-up" nature of American litigation. ${ }^{5}$ In "top-down" justice

* Professor of Law, Loyola School of Law, Los Angeles. Thanks are due for insightful conversations with Jack B. Weinstein, Kenneth R. Feinberg, Samuel Issacharoff, David Jaros, Dana Remus, Jay Tidmarsh and all of the members of the University of Kansas Law Review Symposium on the 50th Anniversary of the Modern Class Action.

1. James M. Newland, Brian P. Moher \& Jason W. Reynar, A Touch of Dutch: Group Actions in the Netherlands, 6 CLASS ACTION 394, 395-96 (2012).

2. Michael J. Madderra, Comment, The New Class Actions in Japan, 23 PAC. RIM L. \& POL'Y J. 795, 808 (2014) (describing class action law in Japan that went into effect in December 2016). See also Deborah R. Hensler, The Future of Mass Litigation: Global Class Actions and Third-Party Litigation Funding, 79 GEO. WASH. L. REV. 306, 307 (2011) [hereinafter Hensler, The Future of Mass Litigation] (noting that at least twenty-one countries have some type of "class action"); Richard A. Nagareda, Aggregate Litigation Across the Atlantic and the Future of American Exceptionalism, 62 VAND. L. REV. 1, 21-25 (2009) [hereinafter Nagareda, Aggregate Litigation].

3. Manning Gilbert Warren III, The U.S. Securities Fraud Class Action: An Unlikely Export to the European Union, 37 BROOK. J. INT'L L. 1075, 1084-90 (2012); see also Samuel Issacharoff \& Geoffrey P. Miller, Will Aggregate Litigation Come to Europe?, 62 VAND. L. REV. 179, 192-97 (2009) (noting that the relationships between counsel, parties, and courts in European systems would be markedly different than in American class actions); Edward F. Sherman, Group Litigation Under Foreign Legal Systems: Variations and Alternatives to American Class Actions, 52 DEPAUL L. REV. 401, 401-03 (2002).

4. See Oscar G. Chase et al., Civil Litigation in Comparative Context 390-400 (Oscar G. Chase \& Helen Hershkoff eds., 2007) (observing the American class action system through a comparative perspective); CHRISTOPHER HODGES, THE REFORM OF ClASS AND REPRESENTATIVE ACTIONS IN EUROPEAN LEGAL Systems: A NEW FRAMEWORK FOR COLLECTIVE REDRESS IN EUROPE 1-3 (2008).

5. See, e.g., Samuel Issacharoff, Regulating After the Fact, 56 DEPAUL L. REV. 375, 377-80 (2007) [hereinafter Issacharoff, Regulating After the Fact] ("What really sets the United States apart 
systems outside the United States like those, for example, in Europe, South America, and Asia, ${ }^{6}$ government actors often compensate victims. The U.S. system, by contrast, traditionally has relied on individuals and their private attorneys to prosecute claims against corporations and others to obtain compensation, while satisfying other socially valuable goals, like deterrence and corrective justice. ${ }^{7}$

Although some question whether the United States truly follows a "bottom-up" approach, ${ }^{8}$ another global trend in complex litigation is emerging. The "bottom-up" approach of the United States, in fits and starts, has begun to converge with other countries' "top-down" approach in aggregate litigation. The new United States model of complex litigation now "involves many different players - class action lawyers, agencies, prosecutors, nonprofits, and other institutions"- in some cases, competing to "prosecute the same defendant, for the same conduct, and with power to compensate victims on a massive scale." 9 Increasingly, state attorneys general, federal prosecutors, agencies, and legislative compensation funds compensate large groups of victims like class actions. ${ }^{10}$ Large institutions, like large mutual funds and state

is the fact that its basic regulatory model is ex post rather than ex ante, a form of regulation that draws heavily on its common-law tradition."); Jack B. Weinstein, Compensation for Mass Private Delicts: Evolving Roles of Administrative, Criminal, and Tort Law, 2001 U. ILL. L. REv. 947, 955 (2001) [hereinafter Weinstein, Compensation for Mass Private Delicts].

6. See, e.g., HodGES, supra note 4, at 3; Jack B. Weinstein, Compensating Large Numbers of People for Inflicted Harms, 11 DUKE J. COMP. \& INT'L L. 165, 176-77 (2001) [hereinafter Weinstein, Compensating]. Large Numbers]; Weinstein, Compensation for Mass Private Delicts, supra note 5 , at 955 .

7. See, e.g., Issacharoff, Regulating After the Fact, supra note 5, at 377-80; Robert Reich, Regulation Is Out, Litigation Is In, AM. ProsPeCt (Dec. 19, 2001), $\mathrm{http}: / /$ prospect.org/article/regulation-out-litigation (“"Regulation' is a bad word. So how are these regulatory issues being handled? Through lawsuits.").

8. See Linda S. Mullenix, Lessons from Abroad: Complexity and Convergence, 46 VILL. L. REV. 1, 12-14 (2001) (describing ways United States complex litigation informally mimics civil law jurisdictions); John H. Langbein, The German Advantage in Civil Procedure, 52 U. CHI. L. REV. 823, 858-61 (1985) (describing similarities between United States complex litigation and managerial approach of German courts).

9. Adam S. Zimmerman, Mass Settlement Rivalries, 82 U. CIN. L. REV. 381, 413 (2013) [hereinafter Zimmerman, Mass Settlement Rivalries].

10. I have discussed these trends in a series of recent articles, which I draw from heavily in Part II.A of this article. See Dana A. Remus \& Adam S. Zimmerman, The Corporate Settlement Mill, 101 VA. L. REV. 129 (2015) [hereinafter Remus \& Zimmerman, The Corporate Settlement Mill] (describing rise of judicial decisions and regulatory policies that encourage corporate mass dispute resolution systems to compete with class actions); Michael D. Sant'Ambrogio \& Adam S. Zimmerman, The Agency Class Action, 112 Colum. L. ReV. 1992 (2012) (describing the rise of federal agency based settlement funds and recommending reforms adopted from complex litigation); Adam S. Zimmerman, Presidential Settlements, 163 U. PA. L. REV. 1393 (2015) [hereinafter Zimmerman, Presidential Settlements] (describing presidential administrations that coordinate and consolidate the resolution of massive disputes); Adam S. Zimmerman, Distributing Justice, 86 
retirement systems, have also taken a larger leadership role in class action lawsuits themselves, relying on changes to United States securities laws in the 1990s. ${ }^{11}$ In many cases, the end result is a large fund managed by the same private administrators who commonly oversee class action settlements. ${ }^{12}$

Now, the same is happening outside the United States. When the United Kingdom amended its class action procedures, it also expanded its own Financial Service Authority's power to seek consumer redress under the 2010 Financial Services Act. ${ }^{13}$ As Sweden, Norway, Japan and Denmark adopted class action procedures over the last decade, they also expanded the authority of state agencies, consumer associations, and other non-governmental organizations to bring "representative actions"

N.Y.U. L. REV. 500 (2011) [hereinafter Zimmerman, Distributing Justice] (tracing the rise of federal agency based settlement funds); Adam S. Zimmerman \& David M. Jaros, The Criminal Class Action, 159 U. PA. L. ReV. 1385 (2011) [hereinafter Zimmerman \& Jaros, The Criminal Class Action] (tracing the rise of massive criminal restitution funds in deferred and non-prosecution agreements between corporate defendants and federal prosecutors).

11. The Private Securities Litigation Reform Act of 1995, Pub. L. No. 104-67, 109 Stat. 737 (1995) (codified in 15 U.S.C. $§ 77 \mathrm{z}-1$ (2012)), provides that the lead plaintiff-the class member with the largest claimed loss who seeks the position - shall select and retain counsel to represent the class. 15 U.S.C. $§ 77 \mathrm{z}-1$ (a)(3)(B)(iii)(I)(bb)-(v) (2012). David H. Webber, Is "Pay-to-Play" Driving Public Pension Fund Activism in Securities Class Actions? An Empirical Study, 90 B.U. L. REV. 2031, 2032-39 (2010) (comprehensively studying public and private institutions after the passage of the Private Securities Litigation Reform Act, or PSLRA).

12. The FTC, for example, regularly uses four claim agents with substantial experience administering class action settlements, including Rust Consulting, Epiq Systems, Analytics Consulting, LLC, and Gilardi \& Co., LLC. Consulting. See Recent FTC Cases Resulting in Refunds, FTC, https://www.ftc.gov/enforcement/cases-proceedings/refunds (last visited Apr. 8, 2017) (listing awards and claim administrators in recent mass refunds). On July 15 , 2013, the SEC approved up to nine firms from which "future fund administrators will be appointed to administer the distribution of disgorgement or fair funds." Delegation of Authority to Director of the Division of Enforcement, 78 Fed. Reg. 46,498-01 46,498 n.1 (Aug. 1, 2013) (to be codified at 17 C.F.R. pt. 200). Before that, in 2010, the United States Attorney and the Security Exchange Commission chose Kenneth R. Feinberg, well known for his experience in private class actions and mass tort settlements, to oversee a \$225 million fund for defrauded stockholders. Liza Mundy, Special Master Kenneth Feinberg is a Mediator's Mediator, WASH. POST (Jan. 14, 2010), http://www.washingtonpost.com/wp-

dyn/content/article/2010/01/13/AR2010011304638.html?hpid=features1\&hpv=national. And back in 2002, the SEC selected Frances E. McGovern, another well-known mass tort scholar and administrator, to oversee payouts to investors from the nation's largest investment banks. See SEC v. Bear, Stearns \& Co., 626 F. Supp. 2d 402, 404 n.1 (S.D.NY. 2009); Press Release, SEC, SEC, NY Attorney General, NASD, NASAA, NYSE and State Regulators Announce Historic Agreement To Reform Investment Practices; \$1.4 Billion Global Settlement Includes Penalties and Funds for Investors (Dec. 20, 2002), https://www.sec.gov/news/press/2002-179.htm.

13. See infra Part I.B. See also Christopher Hodges, Developments in Collective Redress in the European Union and United Kingdom, GloB. Class ACtions EXCH. 5-6 (2010), http://globalclassactions.stanford.edu/sites/default/files/documents/1010\%20Class $\% 20$ Actions $\% 20 \mathrm{U}$ K\%202010\%20Report.pdf. 
on behalf of victims. ${ }^{14}$ Public authorities continue to play an active role in large collective actions in common law systems, like Canada and Australia, and civil law systems, like Brazil. ${ }^{15}$

The convergence of "top down" and "bottom-up" approaches to settling large-scale problems - from the BP Oil Spill to the international response to Volkswagen's scandal over emission "defeat devices" in its cars-raises a host of new questions for the future. Is it fair for prosecutors or agencies, whose primary goals are criminal punishment or regulation, to coordinate with private attorneys who seek to compensate victims? In those countries with federal systems, how should the federal government coordinate with states or provincial authorities?

But "convergence" also presents substantial challenges for judges charged with overseeing different people and institutions, all with different state, institutional or personal interests in a final resolution. How should a judge coordinate or consolidate such cases, if at all? In a world where courts must reconcile competing interests of lawyers, victims, public investors, and local, national and multinational government bodies - each with their own private, regulatory, and criminal enforcement objectives - what level of deference does the court owe to each decisionmaker in that settlement? In short, the global convergence of public and private attorneys commencing overlapping actions creates new pressures on what countries want and expect from their courts.

14. See infra Part I.B; see also, e.g., 5 § LAG OM GRUPPRÄTTEGÅNG (Svensk författningssamling [SFS] 2002:599) (Swed.) (Swedish Group Proceedings Act $\S 5$ ); Lov om mekling og rettergang i sivile tvister (tvisteloven) 17. juni 2005 nr. $90 § 35-3(1)$ (b) (Nor.) (Norwegian Dispute Act, Ch. 35, § 35-3(1)(b)); Robert Gaudet, Jr., Earth to Brussels: Lessons Learned from Swedish, Norwegian, Danish, and Dutch Class Actions for the European Union Debate on Collective Redress (June 2, 2008) (unpublished LL.M. thesis, Stockholm University), http://web.stanford.edu/group/lawlibrary/library/GaudetRobert_thesisJune102008.pdf; Madderra, supra note 2, at 806-08 (describing creation of creation and certification of Qualified Consumer Organizations, which are certified by the Prime Minister and given power to sue on behalf of large groups of consumers in a multi-stage process).

15. See, e.g., 2015 Enforcement Report, CANADIAN SEC. ADM'R 17 (2015), https://www.securities-administrators.ca/uploadedFiles/CSA_ER2015_En.pdf (showing $\$ 111,651,429$ in total restitutionary awards for provincial and territorial securities regulators in 2015); Annual Report 2015-16, Australian Sec. \& InV. Comm'N, 38 (Oct. 14, 2016), http://download.asic.gov.au/media/4058626/asic-annual-report-2015-2016-complete.pdf [hereinafter ASIC ANNUAL REPORT] (highlighting that "[i]n 2015-16, our actions contributed to over $\$ 125.9$ million being refunded or compensated"); Antonio Gidi, The Recognition of U.S. Class Action Judgments Abroad: The Case of Latin America, 37 BROOK. J. INT'L L. 893, 917-18 (2012) (observing that Brazilian class actions initiated by the office of the public prosecutor are "similar to parens patriae standing and associational standing in the United States"). 
This article argues that as government actors assume a more prominent role in mass dispute resolution, courts will also play an important part in the deals they reach. In many countries, judges are charged with overseeing different state and individual actors involved in massive settlements. ${ }^{16}$ And despite the variety of judicial approaches around the world, ${ }^{17}$ in such complex cases, courts may be the only institution able to hear disparate but overlapping claims by public authorities and private parties. Courts may also be in a unique role to ensure that public and private parties effectively police one another as they take steps to reach an overarching settlement. Borrowing innovative approaches from district court judges in the United States, this article explores how countries can adopt measures designed to assist judges in coordinating massive settlements between law enforcement and a variety other interest groups.

Part I outlines the way that the United States and many other jurisdictions are converging on a governmental approach to the compensation of mass claims. The evolving response of public actors to resolve private disputes reflects two different trends. In the United States, as victims' rights advocates successfully encouraged government lawyers, agencies, and legal reformers to adopt a more "victim-centered" justice system, government actors aggressively fought for victim compensation when they settled with corporate wrongdoers. Outside the United States, reformers have pushed for greater public involvement in mass settlements for a different reason-to avoid America's infamous "litigation culture" by placing public actors at the forefront of resolving massive disputes. These converging strategies, across the globe, have

16. HodGES, supra note 4, at 33 (charting required judicial review of 22 out of 25 European Union member states).

17. Judicial review of government actions has varied significantly around the world, as well as over the course of United States history. See, e.g., Francesca Bignami, Regulation and the Courts: Judicial Review in Comparative Perspective, in Comparative LAW AND Regulation: Understanding the Global Regulatory Process 275-286 (Francesca Bignami \& David Zaring eds., Edward Elgar 2016) (summarizing comparative literature on judicial review of administrative agencies); Michael Asimow \& Lisl Dunlop, The Many Faces of Administrative Adjudication in the European Union, 61 ADMIN. L. REV. 131, 144 (2009) (describing different levels of judicial and administrative review across European Union member states); Thomas W. Merrill, Article III, Agency Adjudication, and the Origins of the Appellate Review Model of Administrative Law, 111 ColuM. L. ReV. 939, 946-53 (2011) (providing a background on nineteenth century administrative law); Jerry L. Mashaw, Rethinking Judicial Review of Administrative Action: A Nineteenth Century Perspective, 32 CARDOZO L. REv. 2241, 2248 (2011) [hereinafter Mashaw, Rethinking Judicial Review] ("The nineteenth century federal courts and federal administrative agencies were not in a partnership. They operated in separate spheres. Courts either decided questions de novo on records made in court, or they effectively declined jurisdiction.”). 
created an opportunity for government officials to fashion compensation schemes for large classes of victims.

Part II highlights the conflicts presented when multiple public and private actors seek overlapping remedies in mass litigation. In many cases, government officials will confront the same problems private actors face when they manage complex cases - coordinating cases across different jurisdictions, ensuring adequate participation, overcoming conflicts of interest with victims, and distributing funds fairly. As government actors increasingly seek remedies in litigation that compensate people for widespread harm, judges will have to make difficult decisions about whom to defer to about appropriate settlement awards and proposed structural reforms.

Part III argues that this new "convergence" of public approaches to mass litigation presents a new challenge for judges. In many countries, courts may be one of the few institutions able to hear disparate, but overlapping, claims commenced by public authorities and private parties. Accordingly, Part III explores some ways that countries may adopt measures to assist judges charged with coordinating massive settlements. Borrowing from the United States experience, I suggest that courts should enjoy power to (1) conduct joint hearings involving related actions, (2) coordinate procedures to ensure fair notice and participation, and (3) review settlement agreements to ensure that government and private actors justify the difficult trade-offs they make in a global settlement.

\section{Global Convergence of Public Settlements}

Over the past decade, the United States and many foreign jurisdictions have been converging on a new role for government actors in mass litigation. Much like the emerging scholarship in regulationwhere commentators have identified that public and private actors share "regulatory space" ${ }^{18}$ public and private actors increasingly share

18. See, e.g., Jody Freeman \& Jim Rossi, Agency Coordination in Shared Regulatory Space, 125 HARV. L. REV. 1131, 1173-81, 1209-11 (2012); Eric Biber, The More the Merrier: Multiple Agencies and the Future of Administrative Law Scholarship, 125 HARV. L. REV. F. 78, 78-82 (2012); Jacob E. Gersen \& Adrian Vermeule, Delegating to Enemies, 112 ColuM. L. REV. 2193, 2234-35 (2012); Jason Marisam, Duplicative Delegations, 63 ADMIN. L. REV. 181, 198-218 (2011); Jody Freeman, The Private Role in Public Governance, 75 N.Y.U. L. REV. 543, 617-18 (2000). Scholars are also paying more attention to state-federal coordination. See, e.g., Abbe R. Gluck, Intrastatutory Federalism and Statutory Interpretation: State Implementation of Federal Law in Health Reform and Beyond, 121 YALE L.J. 534, 554-60 (2011); Margaret H. Lemos, State Enforcement of Federal Law, 86 N.Y.U. L. REV. 698, 699-702 (2011). 
"compensatory space" in complex litigation. Historically, in the United States, plaintiff class counsel worked in tandem with prosecutors and regulators to supplement law enforcement efforts, while compensating large groups of victims. ${ }^{19}$ But as public officials in the United States and abroad have been encouraged by reformers to aggressively seek victim compensation, they increasingly find themselves competing with private attorneys in class actions and civil bankruptcies to compensate similar groups of people from the same wrongdoer. And oftentimes, they must do so in different jurisdictions, according to different legal standards, and subject to different degrees of judicial scrutiny.

\section{A. Public and Private Compensation in the United States}

Agencies, ${ }^{20}$ prosecutors, ${ }^{21}$ state attorneys general, ${ }^{22}$ state insurance and securities commissioners, ${ }^{23}$ and even modern Presidential administrations ${ }^{24}$ have assumed a more prominent role in providing mass compensation for large groups of private parties. Such cases may involve blockbuster billion dollar settlements with high profile defendants, like Volkswagen, ${ }^{25}$ British Petroleum, ${ }^{26}$ or Wells Fargo. ${ }^{27}$

19. See, e.g., Howard M. Erichson, Coattail Class Actions: Reflections on Microsoft, Tobacco, and the Mixing of Public and Private Lawyering in Mass Litigation, 34 U.C. DAVIS L. REV. 1, 17, 35-40 (2000).

20. Urska Velikonja, Public Compensation for Private Harm: Evidence from the SEC's Fair Fund Distributions, 67 STAN. L. REV. 331, 362-68 (2015); Zimmerman, Distributing Justice, supra note 10, at 518-19 (describing federal agency based settlement funds); Verity Winship, Fair Funds and the SEC's Compensation of Injured Investors, 60 FLA. L. REV. 1103, 1103-44 (2008).

21. Brandon Garrett, TOO Big To Jail: How Prosecutors COMPromise With CORPORATIONS 138-40 (2014) (describing victim compensation funds established between prosecutors and Bristol Myers Squibb, Computer Assocations and other corporations); Zimmerman \& Jaros, The Criminal Class Action, supra note 10, at 1394.

22. Margaret H. Lemos, Aggregate Litigation Goes Public: Representative Suits by State Attorneys General, 126 HARV. L. REV. 486, 488-91 (2012) [hereinafter Lemos, Aggregate Litigation Goes Public] (describing the rise of state attorneys general lawsuits designed to compensate large groups of victims).

23. See Carlos Berdejo, Small Investments, Big Losses: The States' Role in Protecting Local Investors from Securities Fraud, 92 WASH. L. REV. (forthcoming 2017) (manuscript at 6), https://papers.ssrn.com/sol3/Papers.cfm?abstract_id=2831485 ("In the last two decades, a growing number of states have broadened the remedies available to their securities commissioners in administrative actions to include the ability to request or order restitution on behalf of injured investors.").

24. Zimmerman, Presidential Settlements, supra note 10, at 1399-1401.

25. Press Release, FTC, Federal Judge Approves FTC Order for Owners of Certain Volkswagen and Audi "Clean" Diesels to Receive Compensation (Oct. 25, 2016) https://www.ftc.gov/news-events/press-releases/2016/10/federal-judge-approves-ftc-order-ownerscertain-volkswagen-audi (announcing "landmark" \$10 billion settlement); FTC, Volkswagen 2.0L Settlement (Oct. 2016) https://www.ftc.gov/enforcement/cases-proceedings/refunds/volkswagensettlement (describing $\$ 10$ billion settlement with Volkswagen as "the largest false advertising case 
The sums in such public settlements have yet to reach the totals brokered in large class actions and other private aggregate settlements, but they increasingly are becoming a substantial source of mass compensation in the United States. Over the past decade, federal agencies recovered billions on behalf of misled investors and consumers. $^{28}$ In their most recently published annual reports, the Securities and Exchange Commission ("SEC") claimed over $\$ 4$ billion in disgorgement awards for injured investors, while the Federal Trade Commission ("FTC") announced over $\$ 2$ billion (including a $\$ 1.2$ billion judgement against a single defendant). ${ }^{29}$ The Consumer Financial Protection Bureau ("CFPB") announced over \$200 million in just the first six months of $2016 .{ }^{30}$ Defenders of the CFPB frequently note that, over its short existence, it has restored "nearly $\$ 12$ billion to homeowners, students, servicemen and servicewomen, car buyers, credit card holders, and other borrowers." 31

in FTC history").

26. Well before President Obama encouraged BP to agree to its historic multibillion dollar compensation scheme, see Zimmerman, Presidential Settlements, supra note 10, at 1395-97, it paid over $\$ 53$ million into a victim restitution fund to settle criminal price fixing charges with federal prosecutors. See Deferred Prosecution Agreement at 8, United States v. BP Am. Inc., (No. 07 CR 683) (N.D. Ill. Oct. 24, 2007) (on file with author).

27. Liz Moyer, Wells Fargo to Pay \$1.2 Billion in Mortgage Settlement, N.Y. TIMES (Feb. 3, 2016), https://www.nytimes.com/2016/02/04/business/dealbook/wells-fargo-to-pay-1-2-billion-inmortgage-settlement.html?_r=0; Press Release, CFPB, Consumer Financial Protection Bureau Fines Wells Fargo \$100 Million for Widespread Illegal Practice of Secretly Opening Unauthorized Accounts (Sept. 8, 2016), https://www.consumerfinance.gov/about-us/newsroom/consumerfinancial-protection-bureau-fines-wells-fargo-100-million-widespread-illegal-practice-secretly-

opening-unauthorized-accounts/ (announcing separate multimillion dollar settlements with CFPB, Office of Comptroller of Currency, and City and County of Los Angeles).

28. Zimmerman, Mass Settlement Rivalries, supra note 9, at 383 n.6 (tracing the rise of federal agency-based settlement funds, which collected over $\$ 10$ billion over the past decade).

29. U.S. SEC, AGENCY FInANCIAL REPORT, Fiscal YeAR 2016 ii (2016), https://www.sec.gov/about/secpar/secafr2016.pdf\#contents [hereinafter SEC FY 2016 REPORT] ("The program continued its impressive record this year by filing 868 enforcement actions, the most in the SEC's history, and by obtaining orders for more than $\$ 4$ billion in penalties and disgorgement."); FTC, 2015 ANNUAL Highlights, STATS \& DATA (2015), https://www.ftc.gov/node/943403 (touting awards of $\$ 2$ billion in consumer redress and disgorgement, including $\$ 1.2$ billion recovery against Cephalon for injured purchasers). These totals only reflect aggregate awards; actual distributions to consumers are much lower. The FTC, for example, distributed $\$ 22$ million in 2015 to 844,036 consumers. Id. The SEC reported that it had "held for distribution" over $\$ 3.1$ billion to distribute to investors, but the report does not detail how much investors actually received in 2016. See SEC FY 2016 REPORT, supra note 30, at 106.

30. CFPB, SEMI-ANNUAL REPORT SPRING $2016 \quad 11 \quad$ (2016), https://www.consumerfinance.gov/data-research/research-reports/semi-annual-report-spring-2016/.

31. See, e.g., Editorial Bd., Mr. Trump Goes After Consumer Financial Protection Bureau, N.Y. TiMES (Mar. 22, 2017), https://www.nytimes.com/2017/03/22/opinion/mr-trump-goes-afterconsumer-financial-protection-bureau.html. Over $\$ 7$ billion went to "principal reductions, cancelled debts, and other consumer relief" as a result of its enforcement actions. CFPB, Factsheet, By the 
Federal prosecutors have similarly recovered billions from corporate criminal defendants. Both Presidents George W. Bush and Barack Obama created joint task forces designed to coordinate many different government bodies - all charged with recovering assets on behalf of wronged businesses, investors and homeowners that have now surpassed $\$ 40$ billion. $^{32}$ Even the new Trump administration appears poised to reach a settlement that would forgive millions in loans for students lured into attending a for-profit college. ${ }^{33}$ If finalized, it would become one of the largest "debt forgiveness schemes" for students in United States history. ${ }^{34}$

As I have discussed elsewhere, ${ }^{35}$ the increasing willingness of public attorneys to seek mass compensation reflects three distinct developments in the United States. The first was the development of the victims' rights movement in the 1970s. As victims' rights advocates lobbied public law institutions to create "a more victim-centered justice system," 36 federal

Numbers 1 (2017), http://files.consumerfinance.gov/f/documents/201701_cfpb_CFPB-By-theNumbers-Factsheet.pdf. The CFPB collected $\$ 3.7$ billion in monetary compensation. $I d$.

32. President Barack Obama's 2012 State of the Union Address, for example, announced three new task forces, all responsible for obtaining mass relief for large groups of victims. See Barack Obama, Address Before a Joint Session of Congress on the State of the Union 8 (Jan. 24, 2012) (transcript available at http://www.gpo.gov/fdsys/pkg/DCPD-201200048/pdf/DCPD201200048.pdf). Some examples include a $\$ 13$ billion settlement distributed to injured investors and a $\$ 2$ billion settlement to be distributed to victims of Bernard Madoff's Ponzi scheme. See Ben Protess \& Jessica Silver-Greenberg, In Extracting Deal from JPMorgan, U.S. Aimed for Bottom Line, N.Y. TimES, Nov. 19, 2013, at A1; Danielle Douglas, Government Extracts \$2 Billion in Fines from JPMorgan in Madoff Case, WASH. POST (Jan. 7, 2014), https://www.washingtonpost.com/business/economy/jpmorgan-to-pay-government-17-billion-tosettle-madoff-allegations/2014/01/07/9f62839a-77a6-11e3-b1c5-

739e63e9c9a7_story.html?utm_term=.6d3ff504c553.

33. Shahien Nasiripour, Trump May Give Students Debt Relief that Obama Refused, BLOOMBERG (Mar. 13, 2017), https:/www.bloomberg.com/news/articles/2017-03-13/trump-maygive-students-debt-relief-that-obama-refused (observing that "[u]nder a preliminary accord, the federal government would invite tens of thousands of former students, who more than 20 years ago attended beauty and secretarial schools owned by defunct Wilfred American Education Corp., to petition the Education Department to cancel their unpaid debt"). To be fair, it is unclear whether the settlement talks reflect a change of position between presidential administrations, as this article suggests, or simply the parties' reappraisal of the strength and weaknesses of this particular case. And according to a report by BuzzFeed News, at the time this article was going to press "the Education Department said it has not approved a single fraud claim since the day of Trump's inauguration, while thousands of students already promised forgiveness are still waiting." Molly Hensley-Clancy, 18 States Are Suing Betsy DeVos Over For-Profit College Rules, BuzzFeed News, (July 6, 2017), https://www.buzzfeed.com/mollyhensleyclancy/19-states-are-suing-betsydevos?utm_term=.1tExGO9xy\#.cdK5JMR56

34. Id.

35. See supra note 10.

36. Zimmerman \& Jaros, The Criminal Class Action, supra note 10, at 1394. The Mandatory Victim Restitution Act of 1996, for example, "was hailed as part of a move "toward a more victimcentered justice system,' which would help transform a criminal justice system that Congress 
and state officials have been "encouraged — and sometimes required - to seek victim compensation." 37

Second, large corporate scandals prompted officials across federal and state executive departments - the Justice Department, ${ }^{38}$ federal agencies, ${ }^{39}$ state attorneys general, ${ }^{40}$ and state agencies ${ }^{41}$ - to shift their focus from punishing individual offenders to using coordinated enforcement actions to reform business practices. This evolving public strategy created new opportunities to compensate "large classes of victims harmed by wealthy corporate criminals. 42

Third, government restitution programs reflect a broader trend in corporate dispute resolution. ${ }^{43}$ Worried about risky, "bet-the-company" litigation, business advisors and corporate defense attorneys have embraced mediation and other out-of-court approaches to resolve big cases. $^{44}$ Government actors, in turn, have taken into account those

believed was ignoring the plight of victims." Matthew Dickman, Comment, Should Crime Pay?: A Critical Assessment of the Mandatory Victims Restitution Act of 1996, 97 CALIF. L. REV. 1687, 1688-89 (2009) [footnotes omitted].

37. Zimmerman \& Jaros, The Criminal Class Action, supra note 10, at 1394; Dickman, supra note 37, at 1689 n.20 (quoting Congressman Foley, who at the time observed, "[f]or far too long we have forgotten the innocent victims of crime.").

38. See, e.g., Brandon L. Garrett, Structural Reform Prosecution, 93 VA. L. REV. 853, 855 (2007) (describing the rise of a "new settlement approach" to avoid "collateral consequences of an indictment, while using the prosecution as a 'spur for instutitonal reform"'); Memorandum from Larry D. Thompson, Deputy Attorney Gen., to the Heads of Dep't Components, U.S. Attorneys 4 (Jan. 20, 2003), http://www.americanbar.org/content/dam/aba/migrated/poladv/priorities/privilegewaiver/2003jan20 privwaiv_dojthomp.authcheckdam.pdf [hereinafter Thompson Memo] ("Indicting corporations for wrongdoing enables the government to address and be a force for positive change of corporate culture, alter corporate behavior, and prevent, discover, and punish white collar crime."); Policy Statement on Monetary Equitable Remedies in Competition Cases, 68 Fed. Reg. 45,820-03, 45,822 (Aug. 4, 2003) ("[S]ituations can arise, for example, when significant aggregate consumer injury results from relatively small individual injuries not justifying the cost of a private lawsuit, or when direct purchasers do not sue.").

39. See, e.g., SEC, Putting Investors First: 2009 Performance And AcCountability REPORT 6 (2009), http://www.sec.gov/about/secpar/secpar2009.pdf\#sec1 (observing the SEC's primary goals are to "take prompt action to halt the misconduct, sanction wrongdoers effectively, and, where possible, return funds to harmed investors").

40. See Lemos, Aggregate Litigation Goes Public, supra note 22, at 488-91.

41. Berdejo, supra note 23 (manuscript at 6).

42. Zimmerman \& Jaros, The Criminal Class Action, supra note 10, at 1394.

43. See, e.g., Remus \& Zimmerman, The Corporate Settlement Mill, supra note 10, at 131-32 (describing rise of corporate alternative dispute systems that respond to mass harm); Dana A. Remus \& Adam S. Zimmerman, Aggregate Litigation Goes Private, 63 EMORY L.J. 1317, 1318 (2014) (describing similar trends) [hereinafter Remus \& Zimmerman, Aggregate Litigation Goes Private].

44. See generally Adam S. Zimmerman, The Bellwether Settlement, 85 Fordham L. ReV. 2275, 2276-80 (2017) [hereinafter Zimmerman, The Bellwether Settlement] (describing widespread use of settlement techniques, including "bellwether mediation," to resolve mass litigation without trial); Rory Van Loo, The Corporation as Courthouse, 33 YALE J. ON REG. 547, 548-50 (2016) 
settlement programs in many areas, ${ }^{45}$ including most recently, a series of settlements by Volkswagen to buy back cars following revelations that it deceived regulators with its emission technology. ${ }^{46}$ In such cases, government actors rely on the corporate defendant's ability to efficiently enter into repeat deals, with boilerplate terms, to respond to large numbers of claims. ${ }^{47}$

As public-based litigation grows, cutbacks on class actions have also brought United States systems closer to European and other countries. Samuel Issacharoff, Geoff Miller, Richard Nagareda, and others describe how new limits on complex litigation procedures have, for better or for worse, brought the United States closer to other judicial systems hostile to American style class actions. ${ }^{48}$ Linda Mullenix also describes the ironic enthusiasm of political conservatives for a series of reforms embodied in the proposed Common Sense Legal Reform Act of 1995, that attempted to draw the American legal system closer to its European counterparts - including product liability reform, limits on punitive damages, and additional limits on attorney fee calculations. ${ }^{49}$ That trend

(describing wide variety of ways corporations resolve consumer disputes through privatized dispute resolution); Thomas J. Stipanowich \& J. Ryan Lamare, Living with ADR: Evolving Perceptions and Use of Mediation, Arbitration, and Conflict Management in Fortune 1000 Corporations, 19 HARV. NEGOT. L. ReV. 1, 9 (2014) (describing corporate adoption of alternative dispute systems).

45. Remus \& Zimmerman, The Corporate Settlement Mill, supra note 10, at 144-48, 146 n.75.

46. See, e.g., Press Release, FTC, Class Action Settlements Require Volkswagen to Repair or Buy Back 3.0 Liter TDI Diesel Vehicles (Feb. 1, 2017), https://www.ftc.gov/news-events/pressreleases/2017/02/federal-trade-commission-class-action-settlements-require (stating that, under one settlement, Volkswagen consumers were "eligible to receive approximately $\$ 26,000$ to $\$ 58,000$ for a buyback, depending on the model, mileage, and trim of the car"). The United States Justice Department, the Environmental Protection Agency, and United States Customs and Border Protection also entered into separate plea agreements and civil settlements with Volkswagen. See Press Release, EPA, Volkswagen Clean Air Act Civil Settlement (Jan. 11, 2017), https://www.epa.gov/enforcement/volkswagen-clean-air-act-civil-settlement. Finally, fourty-four state attorneys general collected over $\$ 600$ million on behalf of Volkswagen consumers in their states. Amanda Bronstad, State AGs Secure Groundbreaking Environmental Settlement With Volkswagen, NAT'L $\quad$ L.J. $\quad$ (Mar. $30, \quad$ 2017), http://www.nationallawjournal.com/id=1202782557011/State-AGs-Secure-GroundbreakingEnvironmental-Settlement-With-Volkswagen.

47. See Remus \& Zimmerman, The Corporate Settlement Mill, supra note 10, at 146; Remus \& Zimmerman, Aggregate Litigation Goes Private, supra note 44, at 1318-21 (describing different ways policymakers and agencies regulate corporate dispute resolution); D. Theodore Rave, Settlement, ADR, and Class Action Superiority, 5 J. TORT L. 91, 92-94 (2012) (describing the rise and use of mandatory arbitration and private settlement systems); Jaime Dodge, Disaggregative Mechanisms: Mass-Claims Resolution Without Class Actions, 63 EMORY L.J. 1253, 1293-1302 (2014) (describing arbitration and corporate settlement systems designed to avoid class action litigation).

48. Issacharoff \& Miller, supra note 3, at 192-97; Nagareda, Aggregate Litigation, supra note 2, at 21-25; Sherman, supra note 3, at 401-03.

49. Linda S. Mullenix, American Exceptionalism and Convergence Theory: Are We There 
may accelerate in the coming year as policymakers consider the Fairness in Class Action Litigation Act of 2017, a bill that would impose sweeping new limits on consumer class actions and other entrepreneurial litigation in the United States. ${ }^{50}$

It is the combination of both trends-the decline, but continuing persistence of class action procedures and the rise of governmentinitiated mass settlements - that has brought the United States even closer to the rest of the world. Increasingly, countries around the world are relying on both "bottom-up" and "top-down" approaches to mass compensation.

\section{B. Public and Private Compensation Outside the United States}

The existence of two tracks to resolve large volumes of cases-one private and one public - has similarly begun to take hold in Europe, Latin America and elsewhere. Of course, each jurisdiction has important distinguishing features. And almost all pledge to avoid what they view as problematic American-style litigation. Nevertheless, many foreign countries have begun to experiment with aggregate procedures to resolve large groups of private claims, while increasing the powers of public bodies to do the same.

By aggregate procedures, I mean both "representative" and "multiparty" procedures. ${ }^{51}$ Procedures for "representative litigation" include procedures, like those developed in Dutch collective settlement actions, where the vast majority of claimants seeking relief are not formal parties to the action but, rather, are represented by a similarly situated person or organization. Procedures for "multiparty litigation" involve the resolution of large numbers of related lawsuits, each nominally brought by a different person with formal party status-like English group litigation orders and German model cases in securities litigation. $^{52}$ The United States uses a range of similar procedures to

Yet?, in COMmon Law, Civil LAW and the Future of CATEgories 50-53 (2009) [hereinafter Mullenix, American Exceptionalism].

50. See Bruce Kaufman, House Approves Sweeping Class Action Overhaul Legislation, BLOOMBERG BNA (Mar. 9, 2017), https://www.bna.com/house-approves-sweeping-n57982085020/.

51. See, e.g., Michael D. Sant'Ambrogio \& Adam S. Zimmerman, Inside the Agency Class Action, 126 YALE L.J. 1634, 1647 (2017) (charting different forms of aggregation); Deborah R. Hensler, The Globalization of Class Actions: An Overview, 622 AM. ACAD. POL. \& Soc. SCI. 7, 7-29 (2009) [hereinafter Hensler, The Globalization of Class Actions] (drawing a similar distinction between representative and multiparty litigation in a survey of global approaches to aggregate litigation).

52. See Mariusz Maciejewski, Directorate Gen. For Internal Policies, Overview of 
resolve complex cases - from the Rule 23 class action to the opt-in collective action under the Fair Labor Standards Act to multiparty procedures in multidistrict litigation. ${ }^{53}$

Many have described the rapid spread of representative and aggregate procedures abroad over the past decade. ${ }^{54}$ Representative and aggregate procedures to resolve massive disputes now exist in more than thirty-five countries. ${ }^{55}$ Most vary considerably from the "United States model," which permits contingency fees, allows punitive damages, and precludes subsequent lawsuits to those who do not "opt-out" of the class. They also vary considerably among each other: some limit standing to public bodies or private associations the government has preapproved to commence an action. ${ }^{56}$ But in the majority of jurisdictions, as Deborah Hensler observes, "no party has a monopoly over representative litigation," and "consumers, investors, businesses" may all pursue lawsuits on behalf of others without worrying that certain causes of action "may offend a government in power." over how aggregate lawsuits are financed, the level of court oversight over any potential settlement, whether parties must affirmatively opt in to the lawsuit to participate, as well as whether aggregate litigation is "trans-substantive" or, instead, limited to a few discrete areas of lawlike securities, anti-trust, or consumer fraud.

Existing Collective Redress Schemes in EU Member States 38-39 (2011), http://www.europarl.europa.eu/document/activities/cont/201107/20110715ATT24242/20110715AT

T24242EN.pdf [hereinafter Directorate General] (noting European Member States have adopted four general types of collective redress: "group and representative actions, test case procedures and procedures for skimming off profits").

53. See Yvette Ostolaza \& Michelle Hartmann, Overview of Multidistrict Litigation Rules at the State and Federal Level, 26 REV. LiTig. 47, 48 n.3 (2007) (demonstrating the extent to which the MDL statute has been instrumental in disposing of complex cases).

54. See, e.g., Hensler, The Future of Mass Litigation, supra note 2, at 307-11; Rachael Mulheron, Recent Milestones in Class Actions Reform in England: A Critique and a Proposal, 127 L.Q. REV. 288, 289 (2011); Christopher Hodges, Collective Redress in Europe: The New Model, 29 CIV. Just. Q. 370, 370 (2010); Tiana Leia Russell, Exporting Class Actions to the European Union, 28 B.U. INT'L L.J. 141, 164-79 (2010); John C. Coffee, Jr., Litigation Governance: Taking Accountability Seriously, 110 Colum. L. REV. 288, 302-03 (2010); Hensler, The Globalization of Class Actions, supra note 52; Duncan Fairgrieve \& Geraint Howells, Collective Redress Procedures-European Debates, 58 INT'L \& ComP. L.Q. 379, 380 (2009); Francesco Rizzuto, Does the European Community Have Legal Competence to Harmonise National Procedural Rules Governing Private Actions for Damages for Infringements of European Community Antitrust Rules?, 2 Global Competition Litig. ReV. 29, 29-30 (2009); Issacharoff \& Miller, supra note 3; Nagareda, Aggregate Litigation, supra note 2; Mullenix, American Exceptionalism, supra note 50.

55. Deborah R. Hensler, From Sea to Shining Sea, 65 U. KAN. L. REV. (forthcoming 2017) ("Today, at least 35 jurisdictions in addition to Australia, Canada and the United States, including 21 of the 25 largest economies in the world, permit class actions for some or all legal claims.").

56. Hensler, The Globalization of Class Actions, supra note 52, at 14.

57. Id. 
But despite the variety of aggregate procedures that exist around the world, they share two important features. First, all have converged around developing procedures to peacefully and efficiently resolve large numbers of diffuse claims that arise in an increasingly interconnected global marketplace. Second, despite the different judicial systems, roles and cultures in former Communist bloc countries, civil law and common law jurisdictions, ${ }^{58}$ many imagine some place for their courts to review the overarching fairness adequacy of a massive settlement. ${ }^{59}$

These trends have not gone unnoticed. A number of international conferences have assessed the extent to which countries around the world have been converging on a model of aggregate litigation. In the process, commentators have highlighted three ways that aggregate litigation has converged on a new model inside and outside the United States. First, since the 1980s, commentators compared American judges' hands-on approach to complex litigation to managerial judicial approaches in Germany and other civil law jurisdictions. ${ }^{60}$ Second, commentators have compared U.S. cutbacks on class actions, in Congress and appellate courts, to other countries' general distaste for American entrepreneurial litigation. ${ }^{61}$ Finally, as set out above, commentators have documented how other countries have tentatively begun to adopt United States complex litigation procedures to resolve large numbers of similar claims. $^{62}$

58. Coffee, supra note 55, at 345 ("Although the United States emphasizes checks and balances, Europe (including the United Kingdom) places greater faith in legislative supremacy, and thus it is uncomfortable with an activist style of judicial review, which it fears as antidemocratic.").

59. HoDGES, supra note 4 , at 33 (charting required judicial review of twenty-two out of twenty-five European Union member states); European PARLIAMENT, Resolution of 2 February 2012 on 'Towards a Coherent European Approach to Collective Redress', 2012 O.J. C 239E, http://www.europarl.europa.eu/sides/getDoc.do?type=TA\&reference=P7-TA-2012-

0021\&language $=\mathrm{EN} \&$ ring $=\mathrm{A} 7-2012-0012$ (last updated May 3, 2013) [hereinafter Towards $a$ Coherent European Approach] (recommending strong judicial role to police adequacy of settlement) (last updated May 3, 2013). Notably, however, the EU has not gone as far as some American administrative settlement schemes, like the FTC, which require judicial review of all settlements reached under the Tunney Act.

60. See, e.g., Langbein, supra note 8, at 858-61; Peter H. Schuck, The Role of Judges in Settling Complex Cases: The Agent Orange Example, 53 U. CHI. L. REV. 337, 337-41 (1986).

61. See, e.g., Issacharoff \& Miller, supra note 3, at 181-91; Nagareda, Aggregate Litigation, supra note 2 , at 6-8.

62. See, e.g., Press Release, European Comm'n, Green Paper on Consumer Collective Redress-Questions and Answers (Nov. 27, 2008), http://europa.eu/rapid/press-release_MEMO-08741_en.htm (describing attempts by thirteen member states to adopt class action procedures without elements that made up the American "toxic cocktail"). But see, e.g., Edward D. Cavanagh, The Private Antitrust Remedy: Lessons from the American Experience, 41 LOY. U. CHI. L.J. 629, 640 \& n.79 (2010) (arguing that the term "toxic cocktail" is misleading). 
But there's one form of convergence that has been less discussed. Just as the United States increasingly relies on public actors to settle with corporate wrongdoers and distribute funds like other forms of complex litigation, the same trend has been increasingly taking hold abroad. Great Britain's primary securities and antitrust regulators now enjoy formal powers to collect restitution for victims of securities and financial fraud, much like the SEC, FTC, and the CFPB. ${ }^{63}$ In 2013, the United Kingdom announced that the new competition enforcement authority, the Competition and Markets Authority, would also enjoy this new regulatory redress power. ${ }^{64}$ More recently, the Australian Securities and Investment Commission ("ASIC") touted its own deal to refund 216,000 bank customers $\$ 80$ million "for failing to apply fee waivers, interest concessions and other benefits since 2008." 65

Similarly, public bodies, agencies, and ombudsmen in Brazil, the Netherlands, Sweden, Norway, and Finland, ${ }^{66}$ were also vested with powers to seek mass restitution. In Germany, which has relied on private associations to commence litigation on behalf of large groups of consumers since $1896,{ }^{67}$ public bodies now may commence large aggregate proceedings. ${ }^{68}$ Finally, even as the European Union recommends uniform procedures to member states to respond to billion dollar cross-border disputes, like the London Interbank Offered Rate ("LIBOR") scandal, ${ }^{69}$ it has recommended that public bodies, regulators,

63. HodgES, supra note 4, at 21-22 (describing the "significant extension of the responsibilities" of the British Financial Service Authority and the Office of Fair Trading to pursue "compensation orders" in complex cases).

64. Press Release, Comp. \& Mkts. Auth., New Competition Authority Comes Into Existence (Oct. 1, 2013), https://www.gov.uk/government/news/new-competition-authority-comes-intoexistence.

65. See ASIC ANNUAl RePORT, supra note 15, at 38.

66. Antonio Gidi, Class Actions in Brazil-A Model for Civil Law Countries, 51 AM. J. ComP. L. 311, 382-83 (2003) (comparing Brazilian system to parens patriae cases and other government actions in the United States); Hodges, supra note 4, at 28-29; Klaus Viitanen, Enforcement of Consumers' Collective Interests by Regulatory Agencies in the Nordic Countries, in COLLECTIVE ENFORCEMENT OF CONSUMER LAW: SECURING COMPLIANCE IN EUROPE THROUGH PRIVATE GROUP ACTION AND PUblic AUthority INTERVENTION 81, 83 (Willem H. van Boom \& Marco Loos eds., 2007) [hereinafter COLLECTIVE ENFORCEMENT].

67. HodGES, supra note 4, at 14.

68. See Hans-W. Micklitz, Collective Private Enforcement of Consumer Law: The Key Questions, in COLLECTIVE ENFORCEMENT, supra note 67, at 13-15.

69. Lianna Brinded, EU Prepares Class Action Lawsuits Against Libor and Oil Price Fixing Cartels, INT'L BUS. TIMES (June 7, 2013), http://m.ibtimes.co.uk/eu-price-fixing-libor-oil-probe-gas475861 . 
and prosecutors take charge of commencing actions against corporate wrongdoers on behalf of large groups of victims. ${ }^{70}$

Perhaps the reason why this kind of convergence between the United States and foreign approaches to mass litigation has received less attention is because it seems so unremarkable. Friedrich Hayek long ago recognized that civil law jurisdictions in Europe, South America, and Asia have distinguished themselves from common law jurisdictions like the United States, by relying on centralized forms of public administration to govern. ${ }^{71}$ Unlike the United States judicial system, where judges may spontaneously develop innovative legal rules to respond to new cases and problems, many civil law jurisdictions generally accept and rely upon the expertise and perceived legitimacy of rules developed through a centralized bureaucratic state. ${ }^{72}$ Robert Kagan also famously compared the "particularly American" reliance on lawyers and judges to regulate-what he calls "adversarial legalism"-with centralized bureaucratic approaches used around the world. ${ }^{73}$ Because class actions allow non-state actors to assume the collective responsibility that civil law systems have traditionally reserved exclusively for the state, it perhaps should not be surprising that European systems would simultaneously increase the power of public authorities to accomplish mass compensation. ${ }^{74}$

Nevertheless, the powers conferred on public enforcers are remarkable for at least two reasons. First, these are new formal powers that represent part of the same reform effort designed to adapt collective redress procedures from the United States. ${ }^{75}$ Second, while jurisdictions

70. Towards a Coherent European Approach, supra note 60; see also Rizzuto, supra note 55, at $29-30$.

71. See 1 Friedrich A. HAYEK, LAW, LEgISLATION AND LiBERTY: RULES AND ORDER 95 (1973); Paul G. Mahoney, The Common Law and Economic Growth: Hayek Might Be Right, $30 \mathrm{~J}$. LEGAL STUD. 503, 504 (2001) ("In general, Hayek believed that the common law was associated with fewer government restrictions on economic and other liberties.").

72. HAYeK, supra note 72, at 95; see also Richard A. POSNER, LAW, Pragmatism, AND DEMOCRACY 275-76 (2003) (analogizing Hayek's "spontaneous order" theory to the theory of natural selection); Issacharoff \& Miller, supra note 3, at 209.

73 ROBERT A. KAGAN, ADVERSARIAL LEGALISM: THE AMERICAN WAY OF LAW IX (2003).

74. Indeed, all European countries have long recognized "piggy-back" actions on criminal prosecutions. Since the 1960s, public prosecutors and certified private associations have enjoyed power to seek injunctive relief on behalf of diffuse groups of consumers and investors. The growth of such public forms of redress was sparked by the same pressures that led to dramatic changes for private group litigation in the Federal Rules of Civil Procedure in 1966-the rise of Western Consumerism and mass production. See Hodges, supra note 4, at 14-15.

75. Christopher Hodges, Fast, Effective and Low Cost Redress: How Do Public and Private Enforcement and ADR Compare?, in COMPETITION LAW: COMPARATIVE PRIVATE ENFORCEMENT AND COllective Redress ACROSS THE EU 255, 267 (Barry Rodgers, ed. 2014) [Hereinafter 
outside the United States often rely on centralized administration to regulate, they have not historically relied on those administrative bodies to "regulate by deal" - using litigation and settlements to establish policy and compensate large groups of people. ${ }^{77}$ Third, as discussed above, many reform efforts imagine that courts will play a role in overseeing the ultimate fairness of that large settlement. ${ }^{78}$

As set forth below, the use of public actors to provide private compensation may face some of the same structural problems as private forms of mass compensation-agency costs, inefficiencies, and distributional problems. These concerns, in turn, place increasing pressure on judges who must oversee such cases.

\section{Obstacles to Public Settlements}

The following section highlights the conflicts presented when multiple public and private actors seek overlapping remedies in mass litigation. A vast amount of literature has been devoted to highlighting the problems of coordination, participation, fairness, and conflict in class action litigation. ${ }^{79}$ For that reason, as countries adopt similar procedures

Hodges, Fast Effective and Low Cost Redress] (observing that "[t]he involvement of a public enforcement authority in the payment of compensation is a relatively new technique").

76. Steven M. Davidoff \& David T. Zaring, Regulation by Deal: The Government's Response to the Financial Crisis, 61 ADMIN. L. REV. 463, 465-70 (2009) (outlining their model of "regulation by deal," a process by which government bodies forge deals with individual firms in order to influence their conduct). Steven M. Davidoff Solomon \& David T. Zaring, The Dealmaking State: Executive Power in the Trump Administration 2 (UC Berkeley Pub. Law Research Paper No. 2921407, 2017), https://papers.ssrn.com/sol3/papers.cfm?abstract_id $=2921407$ (considering consequences "if deals [become] a principal mechanism for the promulgat[ion] of government policy, overseen by an executive who promises to be the dealmaker in chief?").

77. Issacharoff, Regulating After the Fact, supra note 5, at 377-80 (comparing United State's ex-post approach to regulation to other countries' ex-ante approach).

78. HODGES, supra note 4, at 33 (charting required judicial review of 22 out of 25 European Union member states); Towards a Coherent European Approach, supra note 60 (recommending strong judicial role to police adequacy of settlement).

79. See, e.g., William B. Rubenstein, A Transactional Model of Adjudication, 89 GEO. L.J. 371,419 (2001) (characterizing class action settlements as large business transactions that exchange bundles of legal rights for money); John C. Coffee, Jr., Class Wars: The Dilemma of the Mass Tort Class Action, 95 Colum. L. REV. 1343, 1348-49 (1995) (observing that "[n]o opening generalization about the modern class action is sounder than the assertion that it has long been a context in which opportunistic behavior has been common.... If not actually collusive, nonadversarial settlements have all too frequently advanced only the interests of plaintiffs' attorneys, not those of the class members.") (footnote omitted); Martin H. Redish \& Nathan D. Larsen, Class Actions, Litigant Autonomy, and the Foundations of Procedural Due Process, 95 CALIF. L. Rev. 1573,1616 (2007) (arguing that modern procedural due process in class actions is insufficient to protect the class members' right to litigate autonomously); Judith Resnick, Managerial Judges, 96 HARV. L. REV. 376, 425 (1982) (arguing that the shift to large class action settlements transforms the judge into a manager and "expands the opportunities for judges to use — or abuse - their power"); 
around the world, they seem equally committed to avoiding the results of the United States system by calling for more settlements brokered with the assistance and oversight of public officials. In some cases, European commentators have expressly pointed to United States' settlements brokered by agencies, prosecutors, and state attorneys general as potential models for reform. ${ }^{80}$

But, as discussed below, government brokered settlements can raise many of the same concerns. Among other things, public actors charged with settling claims may (1) compete or jockey with other players to settle massive cases on behalf of overlapping claimants against the same defendant; (2) struggle to distribute awards efficiently or according to a well-articulated concept of fairness; (3) fail to hear from different stakeholders or victims likely to be affected by the overarching settlement agreement; and (4) may have conflicting interests with the claimants that depend on them for relief.

As government and private actors simultaneously sue to regulate how businesses operate, while compensating people for widespread harm, judges face the difficult task of overseeing the massive settlements they may reach. Those concerns may grow as such dispute resolution systems go global, in cross-border bankruptcies, global antitrust cases, and in mass torts.

\section{A. Challenges of Public Settlements in the United States}

Much like class action litigation, public settlements may struggle to coordinate claims, fairly distribute awards, gather information from diverse stakeholders, and resolve intractable conflicts.

First, public compensation is tough to coordinate and organize. Public actors may compete with other public or private representatives to compensate large groups of people from jurisdiction to jurisdiction. In some cases, public officials and private attorneys may each establish a

\footnotetext{
Jonathan R. Macey \& Geoffrey P. Miller, The Plaintiffs' Attorney's Role in Class Action and Derivative Litigation: Economic Analysis and Recommendations for Reform, 58 U. CHI. L. REV. 1, 3 (1991) ("The absence of client monitoring raises the specter that the entrepreneurial attorney will serve her own interest at the expense of the client.").

80. Hodges, Fast Effective and Low Cost Redress, supra note 75, at 263-67 (advocating for more widespread adoption of public enforcement and alternative distpute resolution to compensate victims); see also, Ethan E. Litwin \& Morgan J. Feder, European Collective Redress: Lessons Learned from the U.S. Experience, in THE LAW AND ECONOMICS OF ClASS ACTIONS 209, 234-37 (James Langenfeld ed. 2014) (proposing that Europeans consider adopting a "regulatory administered compensation system" modeled after the Securities and Exchange Commission Fair Funds and the September 11th Victim Compensation Fund).
} 
settlement fund with money "from the same wrongdoer[s]," on behalf of the overlapping beneficiaries, "often run by [the] same administrators, for the same kinds of harm." ${ }^{\prime 1}$ Such rivalries between public and private actors raise some of the same problems once observed in the United States before the passage of the Class Action Fairness Act-where attorneys competed in different state courts to certify class actions for overlapping groups of people. ${ }^{82}$

For example, a year after private attorneys commenced class actions against the UBS alleging that it had cheated a large number of nonprofits and municipalities, state attorneys general also settled with the same defendants and created a large settlement fund for the same set of victims. ${ }^{83}$ Private attorneys cried foul, arguing the defendants' rush to settle with government lawyers created a race to the bottom that undermined their own settlement efforts. Said one private attorney: "[t]hat's what happens when you have two different processes... the defendant can pick door number one or door number two." ${ }^{" 84}$

81. Zimmerman, Mass Settlement Rivalries, supra note 9, at 387-88 (collecting examples of competing public and private settlements involving the same "wrongdoer" in a wide variety of cases). See also Zachary D. Clopton, Redundant Public-Private Enforcement, 69 VAND. L. REV. 285, 293, 330 (2016) (discussing complications when public and private actors seek overlapping compensation). Duplicative private and public compensation and enforcement are a problem, but should not be overstated. The CFPB, for example, identified 740 enforcement actions by state and local regulators, and in " $88 \%$ of those cases, [was] unable to find an overlapping class action complaint." CFPB, ARBitration StUdy: REPORT TO CONGRESS, PURSUANT TO DODD FranK Wall Street REForm AND CONSUMER PROTECTION ACT $\S$ 1028(a) 17-18 (2015), http://files.consumerfinance.gov/f/201503_cfpb_arbitration-study-report-to-congress-2015.pdf. In her empirical examination of over 240 SEC "fair fund" compensation schemes, Urska Velikonja found that "in more than half of the fair fund distributions- $53.2 \%$ - defrauded investors did not receive compensation in parallel securities litigation." Velikonja, supra note 20, at 371.

82. Geoffrey P. Miller, Overlapping Class Actions, 71 N.Y.U. L. REV. 514, 515 (1996) (observing that "[t]he consolidation of many claims into a single proceeding, which typifies the large-scale class action, creates still another vexing problem: the filing in different jurisdictions of numerous class actions based on a single transaction or occurrence"); Rhonda Wasserman, Dueling Class Actions, 80 B.U. L. REV. 461, 462-63 (2000) (detailing problems of waste in dueling class actions). Competitive class actions still exist, but theirs numbers dropped after the Class Action Fairness Act of 2005 allowed defendants to remove state class actions to federal court with minimal diversity. Pub. L. No. 109-2, § 4, 119 Stat. 4 (2005) (codified at 28 U.S.C. $\S 1332(d)$ (2012)) (granting federal jurisdiction over interstate class actions where the amount in controversy exceeds $\$ 5$ million and at least one plaintiff and one defendant are citizens of different states).

83. Nate Raymond, Plaintiffs Lawyers in Muni Bond Derivative MDL Object to UBS BidRigging Settlement, THE AM. LAW. (May 11, 2011), http://www.americanlawyer.com/id=1202493650539? id=1202493650539\&slreturn=2017030312491 0 . Government attorneys, in response, argued parallel class action litigation frustrated state sovereign interests. Nate Raymond, NY AG Office to Plaintiffs Lawyers: Stay Out of Our BidRigging Cases, THE AM. LAW. Litig. DAILY (May 12, 2011), http://www.litigationdaily.com/id=1202493791095/NY-AG-Office-to-Plaintiffs-Lawyers-Stay-Outof-Our-BidRigging-Cases?slreturn=20170303125241.

84. Zimmerman, Mass Settlement Rivalries, supra note 9, at 382. 
Second, government actors may seek funds against the same insolvent defendant under conflicting standards of fairness. Some creditors entitled to receive money in a potential bankruptcy may be very different than the "victims" defined in criminal law. ${ }^{85}$ The government may not be able to share information about how to locate assets or victims with the trustee in a parallel civil proceeding without jeopardizing a criminal investigation. Worse yet, the dueling compensation systems may produce fights over how to distribute limited assets without any formal process for handling those disputes.

Take Bernard Madoff. After prosecutors finally exposed his decades-long ponzi-scheme, two separate funds were established to compensate his victims. One grew out of civil bankruptcy proceedings, while the other was grounded in the criminal law of restitution and forfeiture. In the first fund, "The Madoff Recovery Initiative," Irving Picard served as a SIPA trustee in a court-appointed bankruptcy, successfully collecting over $\$ 9.5$ billion and distributing out $\$ 5$ billion. ${ }^{86}$ In the second, prosecutors appointed Richard Breeden to oversee a multibillion dollar criminal restitution fund. ${ }^{87}$ Breeden, however, complained that many of the beneficiaries to Picard's fund did not deserve the money. The Madoff Recovery Initiative, he noted, too often paid hedge funds and other claims traders who purchased the right to pursue their claims at a steep discount from direct victims. ${ }^{88}$ Unlike his fund, "widows and orphans" would not get "one thin dime" from Picard's fund. Breeden's concerns reflected the different purposes of compensation in bankruptcy, which is to orderly resolve an organization's outstanding debts, and criminal law, which narrowly defines "victims" as only those proximately hurt by crime. ${ }^{89}$

85. Some victims of fraud, entitled to compensation under a criminal restitution process, may also be third party-defendants in clawback action by a bankruptcy trustee in a parallel proceeding. See Draft Report, Working Group on White Collar Crime, AM. Bar Ass'N, ASSEt Forfeiture AND BUSINESS BANKRUPTCY (Apr. 9, 2014) (on file with author).

86. Diana B. Henriques, Broader Pool of Madoff Victims to Benefit From Fund, N.Y. TIMES (Nov. 18, 2013, 5:43 PM), https://dealbook.nytimes.com/2013/11/18/compensation-fund-set-forfeeder-fund-victims-in-madoff-scheme/.

87. Jordan Maglich, Additional \$2.35 Billion Available for Madoff Victims - But There's a Catch, Forbes, Nov. 25, 2013, https://www.forbes.com/sites/jordanmaglich/2013/11/25/additional-235-billion-available-for-madoff-victims-but-theres-a-catch/\#7ae5c413654d.

88. Henriques, supra note 6.

89. Id. For these reasons, specialists in Bankruptcy worry that criminal restitution funds disrupt bankruptcy's comprehensive "priority" scheme, which commercial creditors depend upon when providing loans. As a result, commercial creditors in bankruptcy are supposed to obtain funds with the same priority as the direct victims of a fraud. Karen Gebbia, Debt and Crime: Inevitable Bedfellows the Intersection of Fraud, Bankruptcy and Asset Forfeiture, 42 GOLDEN GATE U. L. REV. 525, 534-35 (2012) (describing the conflict between "absolute priority" scheme in bankruptcy and 
These competing definitions of fairness - who is a victim under civil and criminal law - also may complicate efforts to achieve a final, orderly resolution. Following a \$2.6 billion government settlement with JP Morgan to compensate Madoff's victims, criminal prosecutors distributed $\$ 1.7$ billion penalty themselves to their "victims," while the bankruptcy trustee, Irving Picard, received a separate settlement for $\$ 543$ million. ${ }^{90}$ To this day, few rules exist to determine whether money collected by a federal prosecutor should go to a bankruptcy fund, criminal restitution fund, or both.

Third, many government actors lack experience gathering accurate information, as well as guidelines to solicit input from private claimants and victims. As a result, there have been some cases where government officers grossly miscalculate victim awards. For example, in 2010, Tom Petters was sentenced to fifty years in prison for a multi-billion dollar Ponzi scheme that wiped out savings for hundreds of his investors. ${ }^{91}$ After the district court received large numbers of objections to the prosecutor's distribution plan, the court found that the government's proposal was riddled with errors, which in some cases, lead to revisions that dropped multi-million dollar claims without any explanation. ${ }^{92}$ Even agencies with more experience in victim compensation, like the SEC, frequently deny parties a voice in the formation of a distribution plan, limit parties' ability to intervene to challenge distributions, and overlook divergent interests in the award..$^{33}$

To be sure, some private administrators appointed to oversee public restitution funds will reach out to potential stakeholders. ${ }^{94}$ Those efforts

criminal restitution). Some also observed that, because the criminal restitution fund sought to compensate so many more direct victims, it has taken much longer to distribute funds. See David Voreacos \& Erik Larson, Why Is the U.S. Still Sitting on \$4 Billion in Madoff Money?, BLOOMBERG, https://www.bloomberg.com/news/articles/2016-02-05/why-is-the-u-s-still-sitting-on-4-billion-inmadoff-money (last updated Feb. 5, 2016, 5:12 PM) (quoting the special master's observation that "I can't just wave a wand").

90. Aaron Smith, JPMorgan's \$2.6 Billion Madoff Reckoning, CNNMONEY (Jan. 8, 2014, 7:33 AM), http://money.cnn.com/2014/01/07/news/companies/jpmorgan-madoff-settlement/. The remaining $\$ 350$ million went to the Office of the Comptroller of the Currency. Id.

91. Annalyn Censky, Tom Petters Gets 50 Years for Ponzi Scheme, CNNMoney (Apr. 8, 2010, 3:31 PM), http://money.cnn.com/2010/04/08/news/economy/Tom_Petters/.

92. United States v. Petters, Crim. No. 08-364, 2010 WL 2291486, at*1-2 (D. Minn. June 3, 2010). We discuss the Petters case in more depth at Zimmerman \& Jaros, The Criminal Class Action, supra note 10, at 1425.

93. Zimmerman, Distributing Justice, supra note 10, at 546-47.

94. The administrator in Computer Associates, Kenneth Feinberg, highlighted his philosophy for doing so, noting that such input was necessary to gather information vital to the distribution plan: "I have a substantive challenge: What should the formula be for the distribution? But I also have a mechanical challenge of how best, in a cost-effective way, to get the money out to eligible claimants 
will likely improve as the SEC, FTC, and other agencies increasingly use and evaluate claim administrators with experience in private class action settlements. ${ }^{95}$ However, no formal rules require those administrators to hear from people or involve them in a distribution plan. ${ }^{96}$ Such oversights, in turn, can complicate the distribution process and, in some cases, add to the total cost of resolving claims.

Fourth, public actors charged with settling claims may experience their own conflicts of interests. Like private class counsel, government settlements may insufficiently account for the interests of diverse claimants. $^{97}$ Government actors may also experience their own conflicts with victims - settling quickly to avoid embarrassing headlines about oversights in their investigations, enforcement actions, or regulatory policies. Following the revelation of a series of financial scandals on Wall Street, Judge Jed S. Rakoff famously rejected a proposed multimillion dollar settlement between the SEC and Bank of America. ${ }^{98}$ Rakoff had harsh words for the agreement, pointing out that the SEC "gets to claim that it is exposing wrongdoing on the part of the Bank of America in a high-profile merger," while Bank of America acceeds to settlement as the cost of doing business. ${ }^{99}$ Underscoring the "cynical" relationship between the public actors and the private defendant, Rakoff concluded: "[a]nd all this is done at the expense, not only of the

and how best to cut checks." Gretchen Morgenson, Giving Away Lots of Money Is Easy, Right?, N.Y. TiMES (Feb. 13, 2005), http://www.nytimes.com/2005/02/13/business/yourmoney/givingaway-lots-of-money-is-easy-right.html?_r=0.

95. See supra note 12 and accompanying text. The SEC, for example, must continually evaluate performance of each administrator under its own regulations. Delegation of Authority to Director of the Division of Enforcement, 78 Fed. Reg. 46,498-01 46,498 n.1 (Aug. 1, 2013) (to be codified at 17 C.F.R. pt. 200). ("Each administrator in the pool will be evaluated annually by the Office of Distributions and, if performance is deemed in compliance with the requirements for selection, will be continued in the pool for another year, up to a total of five years, at which time a selection process for a new pool will take place.").

96. Even in criminal cases, courts may play a very limited role. For example, Petters involved a criminal conviction, where victims were able to object, and the court was authorized to review, the government's victim restitution plan. United States v. Petters, Crim. No. 08-364, 2010 WL 2291486, at*1-2 (D. Minn. June 3, 2010). However, when the government does not prosecute in exchange for a defendant's agreement to a fund, there may be no judicial review. Victims can object to "deferred prosecution agreements" in court, see 18 U.S.C. $\S \S 3161(\mathrm{~h})(2), 3771(\mathrm{a})$ (2012), but even there, judicial involvement is rare — and at such a late stage — victim objections may be too little and too late. Zimmerman \& Jaros, The Criminal Class Action, supra note 10, at 1425 n.191.

97. See, e.g., Official Comm. of Unsecured Creditors of WorldCom, Inc. v. SEC, 467 F.3d 73, 83 (2d Cir. 2006) (citing SEC v. Wang, 944 F.2d 80, 81, 88 (2d Cir. 1991) (confirming that "[s]o long as the district court is satisfied that 'in the aggregate, the plan is equitable and reasonable,' the SEC may engage in the 'kind of line-drawing [that] inevitably leaves out some potential claimants"') (emphasis added).

98. SEC v. Bank of Am. Corp., 653 F. Supp. 2d. 507, 512 (S.D.N.Y. 2009).

99. Id. 
shareholders, but also of the truth." 100 After the parties increased the size of the settlement, Rakoff ultimately held his nose and signed off on the agreement, calling the deal "half baked justice, at best." 101

Arguably, the most serious conflicts may come into play at the state level, where elected government enforcers are vulnerable to capture by the businesses they regulate, as they raise money in local elections. A series of news articles in 2014, for example, chronicled contacts between state attorneys general and the targets of potential enforcement actions that may go entirely unregulated. Some officials dropped investigations or settled actions at discounts shortly after meeting with company lawyers at fundraising events. ${ }^{102}$ More recently, Margaret Lemos and Max Minzner detail how state and federal officers occasionally seek large monetary awards for other self-interested reasons, like when they can retain the proceeds to improve their reputations and fund future enforcement actions. ${ }^{103}$ This kind of "eat what they kill" policy, ${ }^{104}$ according to Lemos and Minzner, is an institutional "arrangement that is common at the state level" and has begun "to crop up in federal law" as well. ${ }^{105}$ To be sure, the vast majority of agreements between government lawyers and businesses involve hard-working lawyers who negotiate good faith, arms-length settlements. But even in these cases, government lawyers confront an inherent conflict between their own enforcement goals and private victims who rely on them for compensation. ${ }^{106}$

100. Id.

101. Louise Story, Judge Accepts S.E.C.'s Deal with Bank of America, N.Y. TIMES (Feb. 22, 2010), http://www.nytimes.com/2010/02/23/business/23bank.html?hp\&_r=0.

102. Eric Lipton, Lobbyists, Bearing Gifts, Pursue Attorneys General, N.Y. TIMES (Oct. 28, 2014), https://www.nytimes.com/2014/10/29/us/lobbyists-bearing-gifts-pursue-attorneysgeneral.html; Eric Lipton, Link Shows How Lobby Firm Cultivates Influence, N.Y. TIMES (Nov. 9, 2014), https://www.nytimes.com/2014/11/10/us/link-shows-how-lobby-firm-cultivatesinfluence.html; Eric Lipton, Missouri Attorney General May Face Inquiry over Money from Lobbyists, N.Y. TIMES (Oct. 29, 2014), https://www.nytimes.com/2014/10/30/us/politics/missourisattorney-general-faces-scrutiny.html; Eric Lipton, Rhode Island Investigating Former State Attorney General, N.Y. TiMES (Nov. 21, 2014), https://www.nytimes.com/2014/11/22/us/rhode-islandinvestigating-ex-attorney-general-on-lobbying-rule.html.

103. Margaret H. Lemos \& Max Minzner, For-Profit Public Enforcement, 127 HARV. L. REV. 853,863 (2014).

104. Id. at 908 .

105. Id. at 854

106. Lemos, Aggregate Litigation Goes Public, supra note 22, at 491 (entrusting state attorneys general to adequately represent distant victims conflates the "consent of the governed" with the "consent of the client"). Richard Nagareda, for example, explores the conflicts states attorneys general experienced settling a historic \$248 billion dispute with the tobacco industry. RICHARD A. NAGAREDA, MASS TORTS IN A WORLD OF SETTLEMENT 184-85 (2007) [hereinafter NAGAREDEA, MASS TORTS]. Even as they sought to reform egregious practices to reduce the public's addiction to smoking, as a result of the settlement, government officials had a perverse incentive to ensure their 
This is not to say that public actors cannot play an important role in mass compensation. The Supreme Court has long emphasized that agencies should receive more discretion than private parties to commence actions that benefit large groups of people. ${ }^{107}$ Public actors often enjoy authority to compensate victims in cases where they lack a private right of action or when they waive rights under a binding arbitration clause. ${ }^{108}$ Congress specifically has charged state attorneys general to police potential conflicts of interests in class actions. ${ }^{109}$ And some agencies, like the FTC, have taken active steps to promote transparency in class settlements. ${ }^{110}$ But it is a mistake to assume that, by simply shifting more authority to public actors, a legal system can overcome difficult questions of coordination, transparency, and fairness in mass settlements.

\section{B. Challenges of Public Settlements Outside the United States}

Coordination problems grow more difficult in highly interdependent, cross-border or global disputes, where regulators and private parties enjoy different powers under different substantive and procedural regimes. Tracing the rise of antitrust settlements between the European Union and global businesses, for example, Professor George Georgiev finds that such settlements can clash with other European regulatory bodies and private actions, as well as with United States regulators. ${ }^{11}$ Negotiating multiple settlements across the United States and Europe

reforms did not work. Id. Otherwise, they risked bankrupting companies that promised billions of unrestricted funds for their state budgets over the next few decades. Id.

107. See, e.g., Gen. Tel. Co. of Sw. v. Falcon, 457 U.S. 147, 156 (1982) (citing Gen. Tel. Co. of Nw. v. EEOC, 446 U.S. 318, 330 (1980)) ("In exercising this enforcement power, the [EEOC] may seek relief for groups of employees or applicants for employment without complying with the strictures of Rule 23.").

108. See, e.g., Velikonja, supra note 20, at 388 ("In a large majority of cases where the SEC created a separate distribution plan, the SEC's action was the only source of compensation from the defendant . . . ."); Myriam Gilles \& Gary Friedman, After Class: Aggregate Litigation in the Wake of AT\&T Mobility v. Concepcion, 79 U. CHI. L. REV. 623, 660 (2012) (arguing that state attorneys general can "fill the void left by class actions" left open by class action waiver and arbitration agreements).

109. Catherine M. Sharkey, CAFA Settlement Notice Provision: Optimal Regulatory Policy?, 156 U. PA. L. REV. 1971, 1973 (2008) (observing that the "overriding purpose" of a provision requiring that states attorneys general receive notice of class action settlements was "to prevent lawyers from crafting abusive settlements favoring themselves over consumers or other injured parties").

110. Press Release, FTC, FTC Seeks to Study Class Action Settlements (Nov. 14, 2016), https:/www.ftc.gov/news-events/press-releases/2016/11/ftc-seeks-study-class-action-settlements.

111. George Stephanov Georgiev, Contagious Efficiency: The Growing Reliance on U.S.-Style Antitrust Settlements in EU Law, 2007 UTAH L. REV. 971, 1031-32 (2007). 
presents obstacles, he observes, because "EU settlements ... apply only to agreements or commercial practices affecting trade among EU member states." 112

To take one prominent example, European Union regulators brokering an historic \$2.3 billion settlement arising out of the LIBOR rigging scandal lacked the same power to collect funds as British and United States regulators against major banks accused of rigging global lending rates. ${ }^{113}$ Among other things, EU regulators were only empowered to collect for antitrust violations requiring proof of a conspiracy, not the somewhat more lenient standard associated with statutory fraud. ${ }^{114}$ The jumble of substantive and procedural rules for collective redress, in light of the LIBOR scandal has, in turn, led to calls to standardize procedures for collective redress across the EU. ${ }^{115}$

Challenges mount when foreign institutions providing mass restitution do not hear from the victims they hope to serve. Following a settlement brokered by United States diplomats, European insurance regulators and private insurers, a fund was established to resolve insurance claims for thousands of Holocaust victims called the International Commission on Holocaust Era Insurance Claims ("ICHEIC"). In the end, ICHEIC successfully provided over $\$ 300$ million to 48,000 Holocaust survivors and their families. ${ }^{116}$ Along the way, however, ICHIEC struggled to compensate victims, just as those same plaintiffs pursued separate but related cases in the United States courts. ${ }^{117}$

One of the reasons why ICHIEC struggled was because it did not include private attorneys from the United States litigation in the design of its compensation process. This reportedly had many unfortunate

\footnotetext{
112. Id. at 1031
}

113. Chad Bray \& Jack Ewing, Europe Sets Big Fins in Settling Libor Case, N.Y. TimEs (Dec. 4, 2013, 8:19 AM), https://dealbook.nytimes.com/2013/12/04/e-u-imposes-1-7-billion-euros-infines-over-rate-rigging-scandal/; see also Understanding the Rate-Fixing Inquiry: Tracking the Global Investigation into How Big Banks Set Crucial Benchmark Interest Rates, Including Libor, N.Y. TIMES, http://www.nytimes.com/interactive/2012/07/16/business/dealbook/20120716-liborinteractive.html?_r=0 (last updated July 28, 2014) (providing a general overview of the LIBOR scandal).

114. See Bray \& Ewing, supra note 113.

115. Brinded, supra note 70.

116. Zimmerman, Presidential Settlements, supra note 10 at 1429. For an insightful history of the litigation, see Michael R. Marrus, Some Measure of Justice: The Holocaust Era RESTITUTION CAMPAIGN OF THE 1990S (2009).

117. In re Holocaust Victim Assets Litig., 424 F.3d 132, 134 (2d Cir. 2005) (rejecting challenges to settlement); In re Holocaust Victim Assets Litig., 105 F. Supp. 2d 139, 141-43, 167 (E.D.N.Y. 2000) (upholding $\$ 1.25$ billion settlement in Holocaust litigation). 
consequences - delaying payouts, imposing burdensome evidentiary requirements, and generating objections from victims and their families. ${ }^{118}$ As I detail elsewhere, "[c]laim processors struggled to identify account holders ... [relying] on rigorous evidentiary rules that often slowed down the claims handling process to a "snail's pace.",119 Years after ICHEIC opened its doors, having racked up more than $\$ 40$ million in expenses, ICHEIC only offered to settle 1,000 claims out of 79,000 presented. ${ }^{120}$ Although ICHEIC hoped to save money and reduce acrimony by bypassing victim's lawyers, the decision to leave out private attorneys ironically may have slowed the compensation process, while increasing costs. ${ }^{121}$

Perceived conflicts of interest between the government and individuals also can undermine perceived legitimacy of a public compensation fund. In the litigation following the meltdown of the Fukushima Daiichi nuclear power plant, parties could obtain compensation through one of three alternative procedures: a private compensation scheme set up by the operators of the private nuclear power plant, the Tokyo Electric Power Company ("TEPCO"); an alternative dispute resolution program financed by the Japanese government; or private collective litigation. ${ }^{12}$ In TEPCO's private process, claimants complained of endless forms, arbitrary distinctions for emotional distress awards, and a "'fox guarding the henhouse' problem in entrusting the compensation process to the party they believed to be responsible for their harms." 123 In the government process, parties

118. Zimmerman, Presidential Settlements, supra note 10, at 1427-29. See also Morris A. Ratner, The Settlement of Nazi-Era Litigation Through the Executive and Judicial Branches, 20 BERKELEY J. INT'L L. 212, 230 (2002) (observing that “[n]o court is monitoring the claims process to make sure that it is equitable, and plaintiffs' counsel ... have been relatively disenfranchised from the implementation process by virtue of the fact that they have no formal role").

119. Zimmerman, Presidential Settlements, supra note 10, at 1429. See also Sidney Zabuldoff, ICHEIC: Excellent Concept but Inept Implementation, in HOLOCAUST RESTITUTION: PERSPECTIVES ON THE Litigation AND ITS LEgACY 260, 261-64 (Michael Bazyler \& Roger P. Alford eds., 2006) [hereinafter Holocaust Restitution]; The Holocaust and Insurance: Too Late, Too Slow, Too Expensive, THE ECONOMIST (July 31, 2003), http://www.economist.com/node/1957197.

120. Zimmerman, Presidential Settlements, supra note 10, at 1430. See also Charles E. Boyle, Holocaust Insurance Claims Panel Faces Recriminations over Delays, INSURANCE JouRnAL (Feb. 11, 2002), http://www.insurancejournal.com/magazines/features/2002/02/11/21936.htm (observing that payouts proceeded at a "snail's pace").

121. Zimmerman, Presidential Settlements, supra note 10, at 1429-30. See also Comprehensive Holocaust Accountability in Insurance Measure, H.R. 1905, 108th Cong. § 2(6)-(8) (2003) (criticizing ICHEIC's process).

122. Eric A. Feldman, Compensating the Victims of Japan's 3-11 Fukushima Disaster, 16 ASIAN-PAC. L. \& POL'Y J. 127, 135 (2015) (providing comprehensive case study of collective redress after the Fukushima disaster).

123. Id. at 138. 
claimed government-appointed mediators discounted awards by an average of $50 \%$ according to unstated guidance. The result pushed many claimants into private litigation, where they faced long delays and substantive hurdles to their class claims. ${ }^{124}$ Even as public compensation systems hope to provide more transparent and efficient payouts than their private counterparts, in practice, they may also lead to delay, confusion and conflict.

Finally, there are times where victims abroad will possess different rights depending upon whether they receive their money from private litigation or government action. The Volkswagen emission litigation has proven to be an interesting example. According to Volkwagen's most recent financial reports, it currently faces class actions and mass actions for its "Dieselgate" in fourteen different jurisdictions outside of the United States and Canada, including: Argentina, Australia, Belgium, Brazil, Ireland, Israel, Italy, Mexico, Poland, Portugal, South Korea, Spain, Taiwan, and the United Kingdom. ${ }^{125}$ At the same time, a series of investigations, reviews, and lawsuits were also launched by federal regulators and forty-four state attorneys general in the United States, as well as regulators in Canada, Germany, Spain, the United Kingdom. ${ }^{126}$ Finally, German, South Korean, and United States prosecutors aggressively pursued parallel criminal investigations, coordinating their investigations, issuing arrest warrants and, in some cases, exacting multimillion dollar fines and penalties. ${ }^{127}$

124. In March 2017, a district court in Japan became the first court to hold TEPCO and the Japanese government negligent for the nuclear disaster. Motoko Rich, Japanese Government and Utility Are Found Negligent in Nuclear Disaster, N.Y. TIMES (Mar. 17, 2017), https://www.nytimes.com/2017/03/17/world/asia/japan-fukushima-nuclear-disaster-tepco-

ruling.html. Individual awards were paltry, however, compared to the 7 trillion yen (over US $\$ 63$ billion) already paid out by TEPCO. Id. The court awarded a total of $\$ 335,000$ to sixty-two evacuated residents, for an evarage of $\$ 5,400$ per person. Id.

125. Volkswagen AG, 2016 Annual Report, at 194-95 (Feb. 24, 2017).

126. Id. at 194-98.

127. Hyunjoo Jin, South Korea Court Issues Arrest Warrant for VW Official in Emissions Scandal, WASH. POST (June 24, 2016), https://www.washingtonpost.com/business/economy/southkorea-issues-warrant-for-arrest-of-vw-official-in-emissions-scandal/2016/06/24/43552e18-3a1d11e6-a254-2b336e293a3c_story.html?utm_term=.a6b6b61f7329. These cross-border actions are just the tip of the iceberg. Volkwagen estimates that investors currently seek over 9 billion euros in various German regional courts, the Netherlands, Austria and other countries. Volkswagen AG, 2016 Annual Report, at 195. As a result, a number of German regional courts must now coordinate and resolve thousands of private class action complaints, see id., as well as parallel actions commenced by foreign state actors, including Norway, South Korea, and California. Jung Suk-Yee, Damage Claim Against Volkswagen: South Korea's NPS to Sue Volkswagen for Damages over Emissions Scandal, BusINESS KOREA (Sept. 30, 2016), http://www.businesskorea.co.kr/english/news/money/16068-damage-claim-against-volkswagensouth-korea $\% \mathrm{E} 2 \% 80 \% 99 \mathrm{~s}$-nps-sue-volkswagen-damages-over. Some commentators argue that such 
The variety of public and private actions against a single defendant like Volkswagon has produced complex rivalries and inconsistent outcomes for similarly situated victims around the world. After the FTC's $\$ 10$ billion settlement with Volkswagen to buy back cars from American consumers, EU officials pressed to get a similar deal for European consumers. The EU has, however, been stymied by inconsistent regulatory approaches among its member states. ${ }^{128}$ On the private litigation front, an American law firm teamed up with a thirdparty litigation funder, MyRight.de, to obtain monetary relief for an estimated 20,000 people. ${ }^{129}$ Because MyRight's business model takes one-third of what it can recover from plaintiffs, much like a standard contingency fee arrangement, the lawsuits only can ask for damages in individually coordinated cases. ${ }^{130}$ Nevertheless, should the EU prevail upon Volkswagen to settle, it could use the threat of injunctive relief to get a deal that would provide Volkswagen owners with new cars. Some observe that this is a more valuable remedy that the parties could not otherwise obtain in their privately-financed actions. ${ }^{131}$

inconsistent approaches may lead to particularly unfair results for investors outside the United States who suffer the same harm. Érica Gorga, The Impact of the Financial Crisis on Nonfinancial Firms: The Case of Brazilian Corporations and the 'Double Circularity' Problem in Transnational Securities Litigation, 16 THEORETICAL INQUIRIES L. 131, 137 (2015) (arguing that, as a result of inconsistent private and public enforcement approaches "Brazilian investors bore most of the costs of the settlement payments to U.S. investors" in securities litigation against two leading Brazilian companies).

128. Stephanie Bodoni \& Karin Matussek, EU Steps Up Pressure on VW in Bid for Bigger Consumer Payouts, BLOOMBERG, https://www.bloomberg.com/news/articles/2016-07-20/vw-saidto-face-coordinated-pressure-from-eu-consumer-groups (last updated July 20, 2016, 8:24 AM). In one interesting development, the EU went so far as to charge individual member states, like Germany, the United Kingdom, and Spain, for failing to take steps to adequately sanction Volkswagen. See Catherine Stupp, Commission Takes Legal Action Against Seven EU Countries over $V W$ Scandal, EURACTIV.COM, http://www.euractiv.com/section/transport/news/commissiontakes-legal-action-against-seven-eu-countries-over-volkswagen-scandal/ (last updated Dec. 9, 2016).

129. Karin Matussek, Volkswagen Proving More Reliable in Court Than on The Road, BLOOMBERG, https://www.bloomberg.com/news/articles/2017-03-16/volkswagen-is-proving-morereliable-in-court-than-on-the-road (last updated Mar. 16, 2017, 7:20 AM).

130. Karin Matussek, German Court Deals Setback to VW Compensation Plan, BloomBERG (Jan. 13, 2017) (observing that "My-Right's business model is taking a third of what it can recover for plaintiffs, so the lawsuits are asking for damages. New cars wouldn't help My-Right.de as it would have to find a way to monetize them") (on file with author).

131. Id. At the time of this writing it appears that administrative authorities in Europe may be getting closer. In March 2017, the European Commission hosted a meeting of 22 consumer protection authorities from across the continent. Theo Leggett, $V W$ Diesel Compensation is On Track in US But Not Elsewhere, BBC NEWS (Mar. 17, 2017), http://www.bbc.com/news/business39255554. They agreed to take "collective action" to put pressure on Volkswagen to provide compensation to million of European consumers. Id. This included "co-ordinated fines on Volkswagen for alleged breaches of consumer law," and making a joint "administrative decision," which could be used to support litigation against the company in national courts across Europe. Id. 


\section{DeVeloping A Judicial Response to Settlement ConVERGENCE}

Despite the variety of judicial approaches around the world, judges in common law and civil jurisdictions are placed in a unique role in mass public and private settlements. Even if the judge will not necessarily be in a position to know when a settlement is substantively fair in such cases, a judge's control over the administration of the case can shape a final settlement in important ways.

Complex litigation scholars and federal judges have long recommended that a single judge ideally should handle overlapping claims arising in massive disputes. ${ }^{132}$ But as disputes move across jurisdictions - involving regulatory and enforcement arms of different nations - such consolidation may not be possible absent international treaties or protocols. Still, judges will require tools to review the ultimate fairness of a mass settlement, particularly where the process may (1) arise in jurisdictions subject to differences in procedure, substantive law and culture; (2) take place on parallel tracks, where public or private parties may fail to communicate with courts about another proceeding that could impact the fairness of a pending settlement; and (3) require the court to review motion practice and settlements to assure public and private actors to enter into arms-length deals.

While this Article cannot solve all of the problems that arise in mass public settlements, some of United States judicial experiments in large private and public settlements offer a way forward. Many include innovations designed to increase communication among judges and parties in mass disputes, where regulators, non-governmental organizations and private parties may otherwise fail to do so. This next part describes three potential reforms and innovations that courts may be able to observe, despite differences in judicial systems: (1) joint judicial hearings, (2) coordinated case management orders and notice procedures between regulators and parties, and (3) limited judicial review to require government actors explain the difficult trade-offs that they may make a mass settlement.

132. Weinstein, Compensating Large Numbers, supra note 6, at 169. (“Aggregation reduces the burdens of multiplicative litigation and allows a single judge to develop a greater familiarity with the case."); Francis E. McGovern, An Analysis of Mass Torts for Judges, 73 TEX. L. REV. 1821, 1826 (1995) (describing "consensus" case management approach to mass torts, including judicial consolidation, coordination, and alternative dispute resolution techniques designed to forge global settlement). 


\section{A. Joint Hearings}

With a few exceptions, government actors generally do not attempt to coordinate their actions with private litigation. There are good arguments for this. After all, government bodies need discretion to determine when to enforce their own regulations. Absent a treaty, prosecutors and regulators across different borders may not be able to bring cases in the same court as one that hears civil cases. Moreover, as a practical matter, government lawyers, regulatory commissions, and consumer ombudsmen in different jurisdictions have different demands, personnel, and budgetary restraints. That means, in the United States and abroad, public officials need discretion to determine how they will divide their resources across different state and provincial lines.

However, when government actors strive to compensate large groups of victims, the failure to coordinate with private consolidated actions, class actions, or bankruptcies raises special problems. When the government resolves a case that compensates many of the same people as a private settlement, public officials may unwittingly confuse potential claimants, while unnecessarily protracting an already complicated dispute.

One potential solution could involve joint pre-motion hearings across jurisdictions between judges. Such joint hearings would respect differences in substantive law across jurisdictions, while encouraging additional coordination among parties. In some cases, joint hearings may be used simply to create a process for parties or court-appointed liaisons to tell judges about new developments in parallel proceedings. Or, if permitted, joint hearings may result in joint opinions, orders or coordination agreements among government entities, trustees, and other people. Joint hearings have long been used in the United States to informally coordinate complex cases. ${ }^{133}$ In the Brooklyn Naval Yard cases, for example, Judge Jack B. Weinstein in the Eastern District of New York famously conducted one of the largest consolidated state and federal court trials, presided over by Justice Freedman and himself. In the process, Judge Weinstein and Justice Freedman coordinated-and

133. In re Joint E. \& S. Dists. Asbestos Litig., 129 F.R.D. 434 (E.D.N.Y. \& S.D.N.Y. \& N.Y. Sup. Ct. 1990). See also, e.g., In re A.H. Robins Co., 88 B.R. 742, 743 (E.D. Va. 1988) (involving a confirmation order jointly issued by district judge Merhige and bankruptcy judge Shelley); see also Byron G. Stier, Resolving the Class Action Crises: Mass Tort Litigation as Network, 2005 UTAH L. REV. 863, 913-15 (2005) (collecting cases); William W. Schwarzer et al., Judicial Federalism in Action: Coordination of Litigation in State and Federal Courts, 78 VA. L. REV. 1689, 1690-91 (1992) (colleting cases, also). 
thus streamlined-discovery, motion practice, and settlement negotiations for thousands of cases. ${ }^{134}$

In joint hearings across jurisdictions, government and private attorneys could be asked to produce information to a panel of judges overseeing different aspects of a mass civil case, enforcement action, or bankruptcy action. The information could include the names of victims scheduled to receive restitution, the basis for the awards, and any other related fines or money awarded to government entities in the public proceeding. ${ }^{135}$ Such efforts may also create opportunities for government attorneys and private lawyers to determine whether or not to consolidate funds through a single scheme should they arrive at a settlement.

Such efforts have already begun between private and public attorneys in United States bankruptcy and criminal proceedings. For example, Judge Rakoff in Southern District of New York and Stuart Bernstein, the Chief Bankruptcy Judge, used joint hearings to coordinate discovery and other motion practice. Sitting together, they ultimately approved an agreement between federal prosecutors and the trustee in the civil bankruptcy that coordinated the way they would distribute and liquidate assets seized by federal marshals. ${ }^{136}$ Such joint hearings are increasingly taking place in cross-border bankruptcy and criminal cases between judges in the United States and Canada.

\section{B. Coordinated Notice and Case Management}

Even when courts cannot coordinate mass settlements, judges should still be able to take steps to assure that settlements receive input from potential claimants. In many cross-border cases, some centralized form of notice may also reduce confusion when public and private attorneys compensate similar claimants entitled to funds in different jurisdictions.

In the United States, a district court may sometimes, pursuant to Rule 23(d), oversee communications by parties and their counsel with putative

134. See In re Joint E. and S. Dists. Asbestos Litig., 129 F.R.D. 434 (E.D.N.Y. \& S.D.N.Y. \& N.Y. Sup. Ct. 1990); In re N.Y.C. Asbestos Litig., 123 B.R. 7 (E.D.N.Y. \& S.D.N.Y. \& N.Y. Sup. Ct. 1990).

135. Such procedures are common when different plaintiff attorneys commence separate actions in different jurisdictions. See MANUAL FOR COMPLEX LiTIGATION (FOURTH) § 22.2 (2014) ("Courts routinely order counsel to disclose, on an ongoing basis past, and pending related cases in state and federal courts and to report on their status and results.").

136. See Coordination Agreement in United States v. Marc Dreier, No. 09-CR-85 (JSR) (S.D.N.Y. 2009); In re Dreier LLP, No. 08 BR 15051 (Bankr. S.D.N.Y. 2009)), (Dec. 12, 2009) (on file with author). 
class members. ${ }^{137}$ In rival government and private litigation over municipal derivatives, ${ }^{138}$ for example, plaintiffs successfully petitioned the district court to review settlement notices. Private attorneys alleged that the state attorneys general settlement asked claimants to waive their rights against the same defendants in the class action litigation they had commenced. ${ }^{139}$ The court rejected the state attorney general's argument that the court could not interfere with their sovereign interests in defining the final settlement terms of their agreement. "In the face of these concerns," the court observed, "BoA and the Settling States respond, essentially, "trust us.","140

The Court ultimately emphasized its independent obligation to "protect the integrity of the potential class and the administration of justice." 141 The court's duty to regulate communications with class members did not change just because the defendant "engaged in thirdparty negotiations with a sovereign state."142 However "pure the intentions of the Settling States maybe," a court "must ensure" notices from the multistate settlement contain "'objective, neutral information' about the nature" of the private settlement, including "the potential remedies available[] and the consequences of electing to opt out of the putative class." 143

Courts also can avoid unnecessary duplication and confusion by informally coordinating across jurisdictions. For example, after Eli Lily reached a $\$ 1.2$ billion settlement with thousands of plaintiffs suffering from diabetes and other ailments associated with Zyprexa, ${ }^{144}$ federal prosecutors sought $\$ 1.4$ billion in restitution in a separate criminal

137. See In re Initial Pub. Offering Sec. Litig., 499 F. Supp. 2d 415, 418 n.13 (S.D.N.Y. 2007); In re Currency Conversion Fee Antitrust Litig., 224 F.R.D. 555, 569 (S.D.N.Y. 2004). Given the potential for abuse or confusion, a district court has "both the duty and the broad authority to exercise control over a class action and to enter appropriate orders governing the conduct of counsel and parties." Gulf Oil Co. v. Bernard, 452 U.S. 89, 100 (1981); Erhardt v. Prudential Grp., Inc., 629 F.2d 843, 846 (2d Cir. 1980) ("It is the responsibility of the court ... to safeguard [class members] from unauthorized, misleading communications from the parties or their counsel.").

138. Hinds Cty. v. Wachovia Bank N.A., 620 F. Supp. 2d 499, 506 (S.D.N.Y. 2009) (describing the litigation's background).

139. Hinds Cty. v. Wachovia Bank N.A., 790 F. Supp. 2d 125, 130 (S.D.N.Y. 2011).

140. Id. at 134 .

141. Id..

142. Id. at 135

143. Id. (citing Kleiner v. First Nat'1 Bank of Am., 751 F.2d 1193, 1203 (11th Cir. 1985)).

144. See Zimmerman \& Jaros, The Criminal Class Action, supra note 10, at 1388. Press Release, Eli Lilly \& Company, Lilly and Plaintiffs' Attorneys Enter into Agreements to Settle $\begin{array}{lllll}\text { Zyprexa(R) Products Liability 2007), } & \text { Litigation }\end{array}$ https://investor.lilly.com/releasedetail2.cfm?releaseid=224308. 
action. ${ }^{145}$ In both cases, the parties sought overlapping awards against the same defendant. Because there were no formal procedures to coordinate criminal and civil actions, ${ }^{146}$ the courts worked together to ensure the civil settlement treated all of the parties across jurisdictions fairly, while minimizing duplicative discovery and restitutionary awards. ${ }^{147}$

As government actors and private parties commence actions, involving overlapping funds, and in some cases, overlapping jurisdictions, some provisions will be needed to ensure courts police communications between parties to ensure fairness, and avoid potential duplication, in large mass settlements. In the United States, courts have responded by taking independent steps to protect the administration of justice by sharing information and creatively managing their cases.

\section{Judicial Review and Judicial Surrogates}

The rise of not one, but two systems that compensate large groups of victims, presents new questions about the role of judicial review in mass settlement practice. As discussed above, private and public settlements may fail to coordinate settlement payouts, gather information about parties or efficiently respond to their needs. Moreover, they may generate conflicts between different victims' groups, as well as with public officials, who themselves may have different missions, focuses, and institutional interests. At the same time, courts may lack information, competence or even the power to oversee the highly complex workings of massive bureaucracies designed to compensate large groups of people. So, what should judges do? What role should courts play when supervising public and private actors, all with competing abilities, interests, and goals in a massive dispute?

145. Lilly ultimately pled guilty to federal criminal charges that it violated the federal Food Drug Cosmetic Act by selling "misbranded" drugs. Press Release, Eli Lilly \& Company, Lilly Resolves Investigations of Past Zyprexa Marketing and Promotional Practices (Jan. 15, 2009), http://newsroom.lilly.com/releasedetail.cfm?Release ID $=359242$.

146. In the civil settlement brokered before Judge Weinstein, Eli Lilly had already set aside over $\$ 43$ million to reimburse Medicare, Medicade, and other welfare expenditures by the United States and 49 state governments. See In re Zyprexa Prods. Liab. Litig., 671 F. Supp. 2d 397, 405 (E.D.N.Y. 2009) (describing parallel proceedings and government payouts).But the United States sought essentially the same medical losses in its own agreement in the Eastern District of Pennsylvania. $I d$.

147. See id. at 402-08 (describing informal coordination between the Eastern District of New York and Pennsylvania). For more on informal and formal judicial coordination, see Zimmerman \& Jaros, The Criminal Class Action, supra note 10, at 1439-40. 
David Jaros and I recently explored similar questions - assessing a wide variety of aggregate settlements reached in United States civil, administrative, and criminal law. ${ }^{148}$ We canvass several possible approaches to judicial review. First, judges could follow the traditional approach to adjudication, deciding the narrow questions presented by a limited number of disputing parties, on a case-by-case basis. ${ }^{149}$ Second, judges could embrace more expansive "public law models" of adjudication, often associated with United States structural reform litigation, where a court actively manages groups of stakeholders in town hall-like proceedings to facilitate large global settlements. ${ }^{150}$ Third, judges could tie judicial review to their "comparative institutional" competence-in each setting, carefully assessing whether courts, officials, or legislatures are better equipped to democratically hear and resolve problems among different people. ${ }^{151}$

We conclude that, at a minimum, judicial review should exist to "alert and press" organizations-private associations of lawyers, government attorneys and public bodies - to improve the way they settle cases. ${ }^{152}$ This kind of review would not mean substituting the parties' negotiated outcomes with what a judge thinks is best. Rather, judicial review would exist to produce: (1) more information about "the parties' competing interests in settlement," (2) greater involvement "by outside

148. David M. Jaros \& Adam S. Zimmerman, Judging Aggregate Settlement, 94 WASH. U. L. REV. (forthcoming 2017) (manuscript at 8-24) [hereinafter Jaros \& Zimmerman, Judging Aggregate Settlement], https://papers.ssrn.com/sol3/papers.cfm?abstract_id=2897217.

149. Lon Fuller is often associated with this model of adjudication. See, e.g., LON L. FULLER, The Forms and Limits of Adjudication, in THE PRINCIPLES OF SOCIAL ORDER 86 (Kenneth I. Winston ed., 1981); Lon L. FUller, The Problems of JuRisPrudenCE $705-08$ (temp. ed. 1949); Donald G. Gifford, The Constitutional Bounding of Adjudication: A Fuller(ian) Explanation for the Supreme Court's Mass Tort Jurisprudence, 44 ARIZ. ST. L.J. 1109, 1154-56 (2012). But see Robert G. Bone, Lon Fuller's Theory of Adjudication and the False Dichotomy Between Dispute Resolution and Public Law Models of Litigation, 75 B.U. L. REV. 1273 (1995) (critiquing the view that Fuller advocated for a narrow model of adjudication).

150. Abram Chayes, The Role of the Judge in Public Law Litigation, 89 Harv. L. Rev. 1281, 1302 (1976); Owen M. Fiss, Foreword: The Forms of Justice, 93 HARV. L. Rev. 1, 39 (1979).

151. Neil K. Komesar, Exploring the Darkness: Law, Economics, and Institutional Choice, 1997 Wisc. L. Rev. 465, 465-66. Neil K. Komesar, Imperfect Alternatives: Choosing INSTITUTIONS IN LAW, ECONOMICS AND PUBLIC POLICY (1994).

152. In so doing, we draw from a long line of scholarship that evaluates the role of courts in the lawmaking process and apply them to settlement practice. See, e.g., Benjamin Ewing \& Douglas A. Kysar, Prods and Pleas: Limited Government in an Era of Unlimited Harm, 121 YALE. L.J. 350, 410 (2011) (approving of court decisions in global warming cases noting that "in the face of many twenty-first century harms, however, 'pluralism' requires not only multiple values, but also multiple institutions."); David A. Sklansky, Quasi-Affirmative Rights in Constitutional Criminal Procedure, 88 VA. L. REV. 1229 1232-33 (2002) (suggesting, in criminal procedure, that courts use "strategies designed to promote ongoing dialogue between the judiciary on the one hand and the political branches on the other"). 
stakeholders," and (3) reasoned justifications "for the trade-offs made by the counsel on behalf of similarly situated parties."

In the United States, this kind of "information-forcing" approach has a long history. American courts have long responded to the growth of administrative systems, like class actions and federal agencies, by asking them to supply good reasons for the critical choices they make. ${ }^{154}$ Since the New Deal, the United States' response to the rise of the administrative state has been to rely on lawyers - subjecting federal agencies to legal norms, evaluating their conduct according to reason, and holding them accountable through judicial review. ${ }^{155}$ Although some commentators worry these trends impose unforeseen costs on regulation, ${ }^{156}$ judicial review still plays an important role by improving information and analysis in modern bureaucracies. ${ }^{157}$

Commentators have imagined a similar information-forcing role for courts that hear class actions and other forms of mass litigation, expressly drawing on courts' experience with public bureaucracies. ${ }^{158}$ Over twenty years ago, Richard Nagareda suggested that just as courts must promote deliberation in administrative agencies, they should do so

153. Zimmerman \& Jaros, Judging Aggregate Settlement, supra note 144, at 5-6.

154. Alexandra D. Lahav, The Law and Large Numbers: Preserving Adjudication in Complex Litigation, 59 FLA. L. REV. 384, 401 (2007) ("The fight over the competence of the federal courts to oversee quasi-administrative agencies is a reenactment of the early twentieth century battle over the ability of the legislature to delegate tasks to administrative agencies.").

155. Daniel R. ERnSt, TocQueville's Nightmare: The Administrative State EMERges IN AMERICA, 1900-1940 7 (2014) (describing the "adverse but not implacably hostile bar" working to ensure the administrative state operated fairly); Jeremy K. Kessler, The Struggle for Administrative Legitimacy, 129 HARV. L. REV. 718, 720 (2016) (noting Ernst's account shows how reformers tamed the administrative state, "in large part by ensuring that lawyers would remain an integral part of the administrative process").

156. Thomas O. McGarity, Some Thoughts on "Deossifying" the Rulemaking Process, 41 DUKE L.J. 1385, 1412 (1992).

157. See Catherine M. Sharkey, State Farm "with Teeth": Heightened Judicial Review in the Absence of Executive Oversight, 89 N.Y.U. L. REV. 1589, 1605 (2015) ("In theory, judicial review ensures that the agency bases its decision on a reasoned analysis of relevant information."); Matthew C. Stephenson, A Costly Signaling Theory of "Hard Look" Judicial Review, 58 ADMIN. L. REV. 753, 755-56 (2006); Motor Vehicle Mfrs. Ass'n v. State Farm Mut. Auto. Ins. Co., 463 U.S. 29, 43 (1983) (holding an agency must offer a "rational connection between the facts found and the choice made") (quoting Burlington Truck Lines v. United States, 371 U.S. 156, 168 (1962)).

158. NAGAREDA, MASS TORTS, supra note 106, at 262-64 (adopting "hard look" review to mass tort fee negotations); Richard Nagareda, Turning From Tort to Administration, 94 Mich. L. Rev. 899, 945 (1996) [hereinafter Nagareda, Turning From Tort to Administration]; Lahav, supra note 154, at 401-32 ("Judicial approval of quasi-administrative agencies should never be automatic, and this principle should probably extend to aggregative settlements, as well as class actions and bankruptcies. Instead, in approving the creation of claims administration facilities, judges should look at these facilities as an extension of their own work and as a kind of public entity.") (footnotes omitted). 
for the large private bureaucracies of attorneys who resolve class action settlements. ${ }^{159}$ Andrew Bradt and Teddy Rave recently have taken this "information forcing" approach a step further-suggesting that courts in complex multidistrict litigation should do more than just promote the flow of information between parties. ${ }^{160}$ They argue that courts, like learned intermediaries, can certify the quality of settlements for their beneficiaries. ${ }^{161}$ In any event, as public and private actors provide overlapping forms of compensation, judges may be pressed to assure injured parties that the compensation they receive was the result of an informed, coordinated and fair process.

It remains to be seen how much the United States experience with public settlements will become a model for judges overseeing similarly complex cases around the world. First, judges abroad may not face the same kinds of problems or pressure because of important differences in their collective redress rules. As set out in the introduction, other jurisdictions impose substantial financial risks on private litigants who pursue class action-like remedies. For these reasons, the kinds of disputes that have surfaced between public and private actors in United States litigation may never materialize in jurisdictions that impose obstacles to private litigation.

Second, in some cases, public actors may establish claim facilities with targeted defendants entirely outside of any court-supervised process. $^{162}$ Even when a court-supervised process exists, in many countries, a separate, specialized administrative body or court may exist to review the agency's action, which may hesitate to coordinate with judges tasked with hearing private claims. ${ }^{163}$

159. See, e.g., Nagareda, Turning From Tort to Administration, supra note 158, at 945 (arguing courts should use "hard look review" in class action settlements to "guard against precisely the kinds of infidelities that lie at the core of the agency cost problem in administrative law").

160. D. Theodore Rave \& Andrew D. Brandt, The Information-Forcing Role of the Judge in Multidistrict Litigation, 105 CALIF. L. REV. (forthcoming 2017) (manuscript at 6) ("[T]he judge should use the MDL process to force the disclosure of information to allows the parties in MDL cases to make informed decision about whether to accept proposed settlements."), https://ssrn.com/abstract=2828461.

161. Id. at 28 (noting that "[h] having developed a degree of expertise in the litigation, the judge is in a better position to process that information.").

162. See, e.g., Hodges, Fast Effective and Low Cost Redress, supra note 75, at 263-67 (describing public actors in Europe that encourage private claim settlement facilities); Frederic Jenny, Worst Decision of the EU Court of Justice: The Alrosa Judgment in Context and the Future of Commitment Decisions, 38 FORDHAM INT'L L.J. 701, 723 (2015) (highlighting rise of EU settlements without any judicial review).

163. See, e.g., Bignami, supra note 17, at 276 (observing that, one of "the first and most enduring contrasts that has been drawn" is "judicial review of administrative action by the ordinary courts in the English common law" tradition and by "special bodies" that are "connected to the 
Third, in civil law jurisdictions, there is significantly less willingness for judges to experiment with judicial power or to challenge administrative determinations. ${ }^{164}$ To the extent civil law judges already defer to other government bodies, perhaps those judges will feel less pressure to confront the challenges public settlements have presented to many United States courts.

But those differences should not be overstated. First, "informationforcing" approaches to judicial review are gaining traction, and some jurisdictions have long embraced the idea that administrative systems should give reasons and explain the tradeoffs they make. ${ }^{165}$ Second, as discussed above, trends outside the United States are changing, particularly as civil jurisdictions manage large dockets and review more administrative actions. Finally, administrative settlement practices continue to spread. For example, shortly after the EU began settling large numbers of antitrust cases, a number of other European countries followed suit, ${ }^{166}$ including France, Belgium, Ireland, and the United Kingdom. ${ }^{167}$ As all of these trends converge, judges may soon confront the problems of coordination, information, and conflict only beginning to surface in public settlements in the United States.

executive branch" in French tradition).

164. Coffee, supra note 55, at 345 ("Although the United States emphasizes checks and balances, Europe (including the United Kingdom) places greater faith in legislative supremacy, and thus it is uncomfortable with an activist style of judicial review, which it fears as antidemocratic."); Susan Rose-Ackerman, American Administrative Law Under Siege: Is Germany a Model?, 107 HARV. L. REV. 1279, 1296 (1994) (highlighting limited judicial review in Germany's administrative law observing "to German democratic theory, political actors do an adequate job of monitoring bureaucratic policymaking activities").

165. See, e.g., Eduardo Jordão \& Susan Rose-Ackerman, Judicial Review of Executive Policymaking in Advanced Democracies: Beyond Rights Review, 66 ADMIN. L. REV. 1, 7 (2014) (comparing approaches to judicial review of administrative action and recommending that judicial review "concentrate on the administrative process, notably by enforcing a widespread duty to give reasons and by assuring generous rights of participation"); Jenny, supra note 162, at 720 (observing rise of EU settlements and noting "when it comes to highly technical or economic assessments... the courts limit themselves to assessing whether the evidence is capable of substantiating the conclusions. In other words, they limit themselves to controlling the internal consistency of the decision"); Jürgen Schwarze, Judicial Review of European Administrative Procedure, 68 LAW \& CONTEMP. PROBS. 85, 93 (2004) ("The obligation to give reasons serves the aim of effective legal protection by enabling courts to carefully review administrative decisions.").

166. Georgiev, supra note 111, at 993 (observing that, before 2004, consent decrees were a "uniquely American invention with no real pre-2004 parallels in either national or EU law." But, since then, settlements not only have become "entrenched" at the EU but lead to "gradual diffusion into the legal systems of a number of EU member states").

167. Id. at 994 (observing that, although the issue remains unsettled, third-party challenges may proceed in court). But see Jenny, supra note 162, at 723 (observing that, to date, EU settlements "are very unlikely to be challenged in court"). 
In such cases, judges need not embrace an expansive public law model of adjudication, or even reject more classical forms of adjudication that rely on reasoned argument. But courts can, at a minimum, organize their proceedings to reduce confusion, raise concerns about conflicts between different parties with different legal entitlements, and ask those actors to explain their decisions.

\section{CONCLUSION}

Judges reviewing the fairness of mass settlements brokered by private and public actors confront similar problems in all forms of government administration - alienation and capture. ${ }^{168}$ The fear in large private representative actions is that the class representative or counsel may sell out the absent members of the class in their own self-interest. ${ }^{169}$ An analogous fear animates large government brokered settlementsthat a government prosecutor or regulator will similarly ignore the interests of the public or potential claimants, when settling with a criminal defendant or a regulated entity. ${ }^{170}$ In both cases, courts have been tasked with reviewing settlements to protect broader constituencies who otherwise lack the ability to directly participate in a trial or settlement that they depend upon for relief.

Although many question whether court-oversight offers a sufficient safeguard against the risks of capture, ${ }^{171}$ there appears to be a growing movement around the world to give courts some role in the oversight of

168. Lahav, supra note 154, at 392 ("There are three central arguments against the administration of claims in the courts: alienation, capture, and error."); Owen M. Fiss, The Bureaucratization of the Judiciary, 92 YALE L.J. 1442, 1452 (1983).

169. See, e.g., John C. Coffee JR, Entrepreneurial Litigation: Its Rise, Fall, AND FUTURE 5 (2015) ("Because no individual class member typically has a fraction of the economic stake at risk that the plaintiff's attorney has, the attorney's actions and decisions are seldom closely monitored by the class members."). See also supra note 79 and accompanying text.

170. See, e.g., SEC v. Citigroup Global Mkts., Inc., 827 F. Supp. 2d 328, 332 (S.D.N.Y. 2011) ("[W]hen a public agency asks a court to become its partner in enforcement ..., the court becomes a mere handmaiden to a settlement privately negotiated on the basis of unknown facts, while the public is deprived of ever knowing the truth in a matter of obvious public importance."); Stop Settlement Slush Funds Act of 2016: Hearing on H.R. 5063, Before the Subcomm. on Regulatory Reform, Commercial and Antitrust Law of the H. Comm. on the Judiciary, 114th Cong. (2016). The Stop Settlement Slush Fund Act, which attempts to bar the Department of Justice from entering into settlements that distribute funds to third-parties out of such concerns was reintroduced into the House this year as H.R. 732. Bruce Kaufmann, Push to Enact Civil Justice Bills Follows Industry Playbook, BLOOMBERG BNA (Feb. 28, 2017), https://www.bna.com/push-enact-civiln57982084551/.

171. Thomas W. Merrill, Capture Theory and the Courts: 1967-1983, 72 CHI-KENT L. REV. 1039, 1044 (1997) (noting the "decline of judicial assertiveness" reflects a "more generalized pessimism about the administrative state"). 
large settlements. United States judicial innovations in massive private and public cases illustrate how judges may continue to shape the deliberation, fairness and efficiency of such actions by improving dialogue between courts, parties and the public. 